\title{
Calikowscy - krakowscy wytwórcy przyrządów naukowych
}

\section{The Calikowski Family - Makers of Scientific Instruments in Krakow}

The article presents biographical entries and professional achievements of three makers of scientific instruments from the Jagiellonian University in Krakow, who were related with each other: Roman Calikowski (1886-1940), his brother Ludwik Calikowski (1889-1961) and Roman's son Roman Julian (1915-1986). These mechanics worked at the Jagiellonian University between 1904 and 1962/1963. Two brothers, Roman and Ludwik, were associated with the University throughout their professional life. During their tenure, the University's research in the field of low temperatures continued, which was initiated in 1883 by Zygmunt Wróblewski (1845-1888) and Karol Olszewski (1846-1915). The main scientific achievement of these researchers was the liquefaction of oxygen, nitrogen and other solid gases. In the late $19^{\text {th }}$ century, Kraków was an important center of cryogenic research, in which the mechanics played important role. Roman Calikowski made instruments for liquefying gases according to the design of Karol Olszewski. Liquefiers from his workshop were ordered, inter alia, by universities in Chicago, Mumbai and Madrid. A few instruments from his workshop have been preserved in the collections of the Jagiellonian University. Ludwik Calikowski worked as a maker of scientific instruments in a university cryogenic laboratory. He served and maintained the apparatus for liquefying gases and made instruments, although none have survived to this day. Roman Julian Calikowski took over the workshop after his father. Until 1950 he ran his own company, which made simple small microscopes, surveing instruments, psychotechnical devices and other instruments. After moving to Warsaw, he devoted himself to scientific work.

Roman Calikowski's products, especially cryogenic apparatus, represented a high level of workmanship and safety. This is evidenced by numerous orders for its liquefiers submitted by foreign laboratories. The company of Roman Julian Calikowski, apart from a wide range of instruments it offered, used to repair photographic and measuring equipment. 
Keywords: maker of scientific instruments, the Jagiellonian University, gas liquefier, cryogenic instruments, scientific instruments, Calikowski, making scientific instruments

Słowa kluczowe: mechanik uniwersytecki, Uniwersytet Jagielloński, skraplarka gazów, instrumenty kriogeniczne, przyrządy naukowe, wytwórczość przyrządów, Calikowski

W wytwórczość przyrządów badawczych i dydaktycznych w Krakowie z końcem XIX i w pierwszej połowie XX w. istotny wkład wnieśli trzej przedstawiciele rodziny Calikowskich: Roman Calikowski, Ludwik Calikowski - brat Romana i Roman Julian Calikowski syn Romana. Wszyscy związani byli, przynajmniej w części swej kariery zawodowej, z Uniwersytetem Jagiellońskim.

Zawodowa działalność Calikowskich zasługuje na szczególne przypomnienie z kilku powodów. Po pierwsze mieli oni, głównie Roman i Ludwik, znaczący udział w eksperymentach w obszarze fizyki niskich temperatur. Z początkiem XX w., kiedy Roman Calikowski rozpoczynał pracę na Uniwersytecie Jagiellońskim, krakowska pracownia kriogeniczna utraciła już wprawdzie pozycję wiodącej w Europie, była jednak nadal jednym z niewielu ośrodków naukowych zajmujących się skraplaniem gazów, badaniem ich właściwości fizykochemicznych w niskich temperaturach oraz unowocześnianiem aparatury kriogenicznej. Roman Calikowski, podobnie jak inny mechanik uniwersytecki tego okresu Władysław Grodzicki (1862-1927), wykonywał skraplarki gazów na zamówienie europejskich laboratoriów podejmujących tę modną wówczas tematykę. Były to przyrządy wysokiej klasy, rozsławiające osiągnięcia Zygmunta Wróblewskiego (1845-1888) i Karola Olszewskiego (1845-1888) w zakresie kriogeniki. Ludwik Calikowski, który uczył się zawodu u swego brata, był sprawnym mechanikiem. Dzięki jego wiedzy i umiejętnościom uniwersytecka pracownia kriogeniczna uruchomiona została po zniszczeniach wojennych. Roman Julian Calikowski wprawdzie krótko związany był z Uniwersytetem Jagiellońskim, ale podtrzymywał tradycje rodzinne. W zakładowym warsztacie prowadzonym przez ojca uczył się zawodu, by potem, już do własnej firmy, przyjąć na praktykę swego kuzyna Jana - syna Ludwika Calikowskiego.

W niniejszym artykule uwaga skupiona zostanie głównie na dokonaniach Calikowskich w obszarze wytwórczości przyrządów pomiarowych i specyficznych aparatów badawczych. Zachowane do dziś historyczne przyrządy z ich warsztatów dają obraz ówczesnych możliwości technicznych i umiejętności tych mechaników.

To, co również zasługuje na podkreślenie to patriotyczna postawa Romana i Ludwika. Podczas okupacji, z narażeniem życia, podejmowali oni próby ukrycia i zabezpieczenia cennej aparatury badawczej będącej pod ich opieką.

W funkcjonowaniu dziewiętnasto- i dwudziestowiecznych uczelnianych pracowni przyrodniczych pomoc mechanika w pracach dydaktycznych i naukowych była niezbędna. Jego zadaniem była nie tylko dbałość o stan techniczny przyrządów, współpraca przy eksperymentach, zestawianie aparatury, lecz także wykonywanie jednostkowych przyrządów według indywidualnych projektów i potrzeb badawczych profesora. Funkcje te Calikowscy wypełniali ciesząc się nieposzlakowaną opinią, o czym świadczą wypowiedzi ich przełożonych oraz przyznane przez uczelnię medale. Funkcjonowali oni w strukturze uczelni jako mechanicy pracujący dla danych zakładów, nie jako mechanicy realizujący 
potrzeby całego uniwersytetu. Mechanikami uniwersyteckimi w tym okresie byli Władysław Grodzicki i Leon Józef Kowalski (1900-1971). Warto tu krótko przypomnieć historię urzędu mechanika uniwersyteckiego.

\section{Mechanicy Uniwersytetu Jagiellońskiego}

Zagadnienia związane z prawnymi regulacjami stanowiska mechanika uniwersyteckiego omawiał Maciej Gablankowski w pracy magisterskiej zatytułowanej Mechanicy Uniwersytetu Jagiellońskiego (1787-1939) wykonanej w 2004 r. pod kierunkiem prof. dr hab. Andrzeja Banacha w Zakładzie Historii Kultury i Oświaty Instytutu Historii Uniwersytetu Jagiellońskiego'. Tematykę dziejów tego urzędu podjął Maciej Gablankowski ponownie jako uczestnik sesji „Polscy wytwórcy aparatury naukowej” zorganizowanej przez Komisję Historii Nauki Polskiej Akademii Umiejętności w roku 2006². Jak wykazał w swych badaniach, stanowisko głównego mechanika uniwersyteckiego utrzymywane było do 1939 r.

Pierwszym zatrudnionym mechanikiem był Wojciech Rączkowski³. Przyjęty został do pracy w Szkole Głównej Koronnej w 1787 r. przez prof. Feliksa Radwańskiego (1756-1826). Rączkowski pełnił opiekę nad Gabinetem Mechaniki założonym przez Feliksa Radwańskiego $^{4}$. Kolejni mechanicy uniwersyteccy to: Tomasz Taborski (w latach 1817-1825), Jacenty Taborski (1825-1857), Johann Niemetz (1858-1887), Stanisław Freund (1891-1893), Wilhelm Regdasiński (1893-1896), Władysław Grodzicki (1897-1927), Leon Józef Kowalski (19291954) ${ }^{5}$. Wybuch II wojny w 1939 r. spowodował przerwanie normalnego funkcjonowania Uniwersytetu. W powojennej strukturze uczelni etat głównego mechanika uniwersytetu nie został przywrócony. Utrzymane zostały stanowiska mechaników zakładowych.

Lata pracy na Uniwersytecie Jagiellońskim trzech przedstawicieli rodziny Calikowskich to blisko sześćdziesięcioletni okres: 1904-1962/1963. W niniejszym artykule omówiona zostanie ich działalność i spuścizna.

\section{Roman Calikowski}

Roman Calikowski urodził się 6 sierpnia 1886 r. w Krakowie jako najstarszy z czterech synów Wojciecha Calikowskiego i Franciszki z domu Herjan/Heryan, zamieszkałej w Prądniku Białym nr 62 koło Krakowa6 ${ }^{6}$ Z małżeństwa z Walerią (1889-1961) z domu Giermek miał dwoje dzieci: Krystynę (1922-2012) i Romana Juliana (1915-1986).

1 M. Gablankowski, Mechanicy Uniwersytetu Jagiellońskiego (1787-1939), praca magisterska pod kierunkiem prof. dr hab. Andrzeja Banacha, Zakład Historii Kultury i Oświaty, Instytut Historii Uniwersytetu Jagiellońskiego, Kraków 2004.

2 Idem, Mechanicy Uniwersytetu Jagiellońskiego, [w:] Polscy wytwórcy aparatury naukowej, red. A. Strzałkowski, Kraków 2006, s. 45-60 (Monografie Polskiej Akademii Umiejętności, t.10).

3 Nie są znane daty urodzenia i śmierci Wojciecha Rączkowskiego.

4 M. Gablankowski, Mechanicy, praca magisterska, s. 9. O Wojciechu Rączkowskim niewiele wiadomo. Nie jest znana data zakończenia przez niego pracy dla Szkoły Głównej Koronnej.

5 Daty ujęte w nawiasach obejmują lata pracy na stanowisku mechanika uniwersyteckiego.

6 AUJ, sygn. SII 620 Roman Calikowski, teczka osobowa, Wykaz policzalnego czasu służby do wysługi emerytalnej. Nie są znane daty życia Wojciecha i Franciszki Calikowskich. 

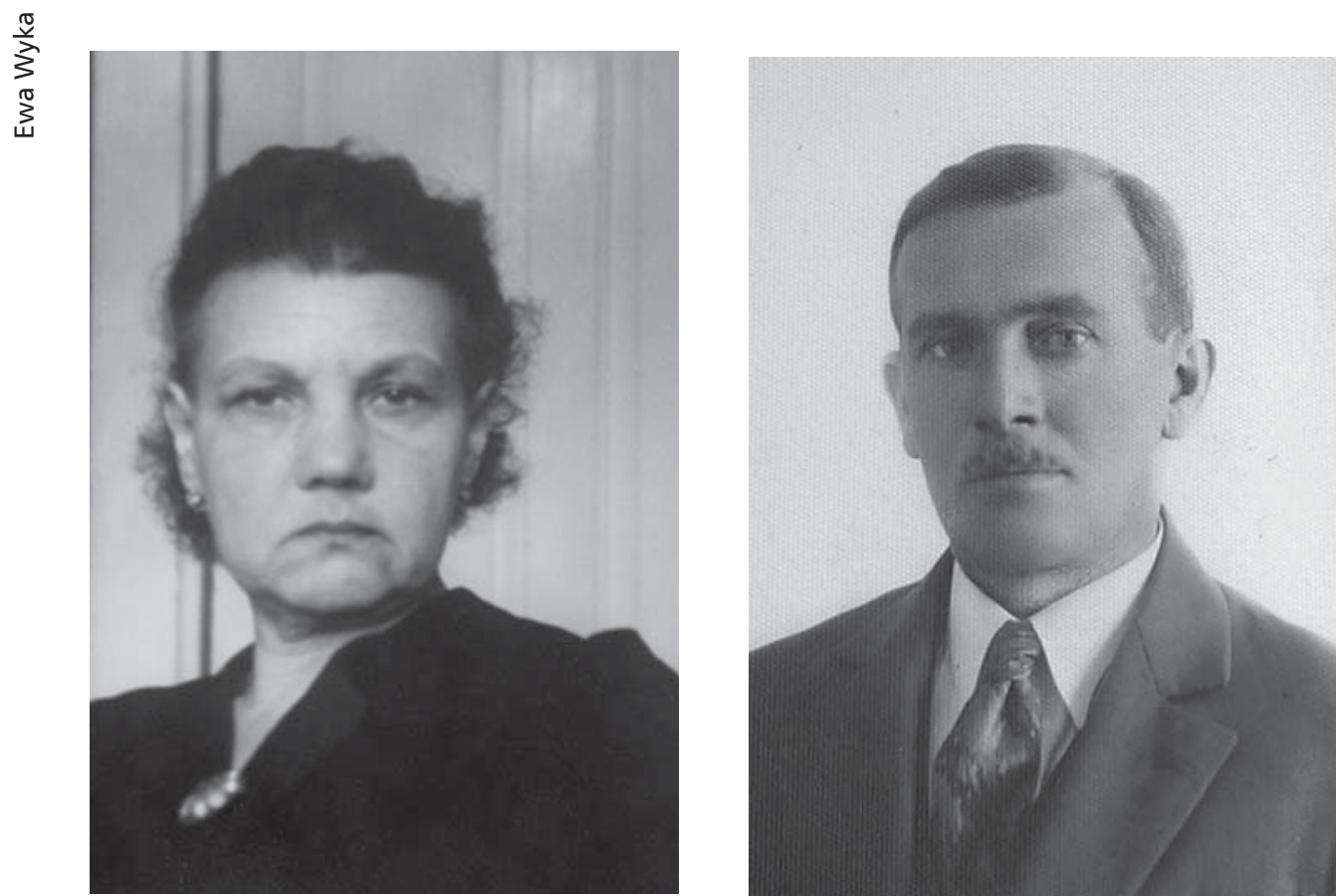

Ryc. 1. Fotografia Romana i Walerii Calikowskiej z domu Giermek, lata trzydzieste XX w., wł. Maria Calikowska, reprod. Ewa Wyka.

Z Uniwersytetem Jagiellońskim związany był praktycznie przez całe swoje życie zawodowe, tj. od 1904 r. do 1940 r. Do pracy mechanika był on dobrze przygotowany. Ukończył dwuletnią Państwową Szkołę Przemysłową Uzupełniającą w Krakowie „z ogólnym postępem dobrym"7. Szkoła rozpoczęła funkcjonowanie w roku szkolnym 1888/1889. Początkowo mieściła się w Krakowie przy ul. Gołębiej $20^{8}$. Naukę pobierać można było na czterech wydziałach: budownictwa, mechaniczno-technicznym, chemiczno-technicznym i od roku 1889/1900 na wydziale przemysłu artystycznego. W ramach szkoły uzupełniającej prowadzone były wieczorowe i niedzielne kursy adresowane do terminatorów i czeladników zatrudnionych w zakładach rzemieślniczych.

Zawodu Roman Calikowski uczył się również w latach 1901-1904 u mechanika Zakładu Fizjologicznego UJ Franciszka Zeleny9 . Przez kilka miesięcy r. 1904 pracował Calikowski w Zakładzie Mechanicznym Stanisława Leśniakowskiego w Krakowie przy ul. Grodzkiej 48 (14 lipca - 29 listopada 1904). Stanisław Leśniakowski wykonywał m.in. przyrządy kosmetyczne wg dr. medycyny Leona Lustera, służące do elektryzowania ciała i skóry gło-

7 AUJ, sygn. SII 620 Roman Calikowski, teczka osobowa, Pismo z dnia 28 XI 1929 r. nr L.10.988/29 w sprawie przeszeregowania.

8 K. Krzyżanowski, Zarys historii i rodowód Zespołu Szkół Mechanicznych Nr 1 w Krakowie 1834-1984, Kraków 1989. W 1896 r. szkoła została przeniesiona do budynku przy ul. Krupniczej 12, a także do wynajętych w 1899 r. pomieszczeń w budynku nr 7 przy tej samej ulicy. W roku 1913/1914 otrzymała nowa siedzibę przy al. Mickiewicza 5 .

9 AUJ, sygn. SIl 815 Fizjologia 1849-1937; M. Gablankowski, Mechanicy, praca magisterska s. 48. Franciszek Zelena pracował jako mechanik na Uniwersytecie Jagiellońskim przy Katedrze Fizjologii w latach 1897-1904. W 1904 r. objął posadę mechanika w Zakładzie Fizycznym we Lwowie. Nie są znane daty urodzenia i śmierci. 
wy. W 1904 r. na Krajowej Wystawie Przemysłu Metalowego w Krakowie Leśniakowski wystawiał jako wytwórca trzy rodzaje przyrządów do elektryzowania ${ }^{10}$. Roman Calikowski zapewne znał te wyroby z okresu swojej praktyki.

Z Uniwersytetem Jagiellońskim Roman Calikowski związał się od 1 grudnia 1904 r. Zatrudniony został wówczas na zasadzie kontraktu służbowego jako mechanik w Zakładzie Fizjologii UJ u prof. Napoleona Cybulskiego (1854-1919). Przyjęty został na miejsce mechanika Stanisława Kucharczyka, który „okazał się nieodpowiedni"11. Do jego obowiązków należało „utrzymywać wszystkie przyrządy Zakładu w stanie takim, aby w każdej chwili mogły być do doświadczeń użyte"12. Miał również obowiązek obsługiwać przyrządy podczas eksperymentów, czyścić je po zakończonych pracach. Obowiązek ten dotyczył przyrządów szczególnie precyzyjnych i cennych, prace przy innych wykonywać mogła „obsługa”. Miał również obowiązek wykonywania nowych aparatów według wymagań kierownika zakładu Napoleona Cybulskiego. Prace te wykonywał w zakładowym warsztacie mechanicznym z użyciem uniwersyteckich narzędzi i materiałów. W Zakładzie Fizjologicznym pracował Roman Calikowski do 6 października 1908 r., kiedy to powołany został do rocznej służby w armii austriackiej. W jej ramach zatrudniony był (6 września 1909-26 listopada1909) w firmie Franz Steflitschek und Sohn w Wiedniu, gdzie „pracował jako mechanik, ku zadowoleniu przełożonego"13. Zwolniony jako jedyny żywiciel rodziny, powrócił na swe stanowisko w Zakładzie Fizjologicznym (1 stycznia 1910 r.), które zajmował do 31 maja 1911 r.

Jak pisze prof. Napoleon Cybulski:

Przez cały ten czas pełnił swoje obowiązki bardzo sumiennie, wszystkie roboty wchodzące w zakres obowiązków wykonywał zupełnie samodzielnie, ku mojemu zupełnemu zadowoleniu, zachowywał się trzeźwo i uczciwie, co na jego żądanie potwierdzam ${ }^{14}$.

Od 1 czerwca 1911 r. został przeniesiony na stanowisko starszego laboranta w I Zakładzie Chemicznym UJ, które obejmował do 1 listopada 1918 r. ${ }^{15}$ Przejął je po Karolu Jetlebie (1858-1931), który z końcem marca 1910 r. odszedł na emeryturę ${ }^{16}$. W 1914 r. Roman Calikowski został zmobilizowany do 16. Landwehrinfanterieregiment Krakau (16 Pułku

10 AUJ, sygn. S.II. 620 Roman Calikowski, teczka osobowa; Katalog Krajowej Wystawy Przemysłu Metalowego, Kraków 1904, s. 88, 110. W 1924 r. dr Leon Luster założył w Krakowie firmę „Doktora Lustra Preparaty Kosmetyczno-Lekarskie Miraculum", bwpr.pl/historia-miraculum-s-a/ [dostęp 10.04.2018].

11 AUJ, sygn. SIl 620 Roman Calikowski, teczka osobowa, pismo N. Cybulskiego do Senatu UJ nr 1698 z dnia 19 XII $1904 r$.

12 AUJ, sygn. SII 620 Roman Calikowski, teczka osobowa, Kontrakt służbowy, 3 XII 1909 r., s. 1.

13 K. Siebinger, D. Gitschthaler, Die Historische Sammlung der Fakultat für Physik Universität Wien, Wien, 2004, s.115; AUJ, sygn. SII 620 Roman Calikowski, teczka osobowa, pismo nr L. 10.889/29 z dnia 28 XI 1929 r.; także informacja w: AUJ, sygn. SII 620 Roman Calikowski, teczka osobowa, pismo z nominacją CK. Namiestnictwa XIV.18/9 z dnia 3 V $1911 \mathrm{r}$.

14 AUJ, sygn. SII 620 Roman Calikowski, teczka osobowa, Świadectwo z dnia 25 IV 1910 r.

15 M. Gablankowski, Mechanicy, praca magisterska, s. 49. W okresie pracy w I Zakładzie Chemicznym był leczony w Klinice ocznej UJ w dniach 17 XI - 6 XI 1912 r. W piśmie tym znajduje się informacja, że był ubezpieczony od nieszczęśliwych wypadków w pracy; AUJ, sygn. SII 620 Roman Calikowski, teczka osobowa, pismo do Senatu UJ nr 1691 z dnia 16 VII 1913 r.

16 AUJ, sygn. SII 620 Roman Calikowski, teczka osobowa. Opis konkursu na mechanika przedstawia Karol Olszewski w piśmie do Senatu UJ nr 563 z dnia 1 III 1911 r.; także pismo prof. Hoyera do Senatu UJ nr 510 z dnia 18 VI 1910 r.; AUJ, sygn. SII 620, Karol Jetleb, teczka osobowa. K. Jetleb zatrudniony był na stanowisku mechanika przy I Zakładzie Chemicznym od 1893 do 1910 r. 
Piechoty Obrony Krajowej „Kraków”) ${ }^{17}$. Od 2 listopada 1918 r. przeszedł „wprost ze służby austriackiej do polskiej", jak pisze w swym życiorysie ${ }^{18}$. Odznaczony został Srebrnym Krzyżem Zasługi Cywilnej (Silbernes Verdienstkreuz) dnia 22 grudnia 1917 r. nadanym przez cesarza Franciszka Józefa ${ }^{19}$. Otrzymał srebrny krzyż za długoletnią służbę (1938 r.).

Po powrocie do Krakowa został mianowany na etat mechanika w Akademii Górniczej (1 lipca 1919-31 sierpnia 1921)20. W ostatnich miesiącach pracy Senat Akademii Górniczej przyznał mu nagrodę w wysokości dziesięciu tysięcy marek za „precyzyjne wykonywanie aparatów fizycznych"21. Z dniem 1 września 1921 r. powrócił do pracy na Uniwersytecie Jagiellońskim jako pomocnik mechanika w Zakładzie Fizycznym. Pracował tam do końca życia - od 1 października 1931 r. jako „starszy funkcjonariusz z obowiązkiem mechanika"22, a od 1 stycznia 1938 r. jako starszy mechanik ${ }^{23}$.

Roman Calikowski posiadał tytuł mistrza dyplomowanego ślusarstwa precyzyjnego, był członkiem Cechu Mechaników, Optyków, Grawerów, Zegarmistrzów, Jubilerów i Złotników w Krakowie. Wchodził w skład Komisji Egzaminacyjnej w Izbie Rzemieślniczej w Krakowie ${ }^{24}$. W 1938 r. otrzymał dyplom instruktora praktycznego nauczania ślusarstwa precyzyjnego wydany w Warszawie ${ }^{25}$. Jego starania o uzyskanie dyplomu popierał ówczesny kierownik Zakładu Fizycznego prof. Konstanty Zakrzewski (1876-1948) „przede wszystkim dlatego, że istotnie spełnia wobec studentów, magistrantów i doktorantów rolę instruktora konstrukcji przyrządów precyzyjnych - częstokroć bardzo zawiłych"26.

Zakład Fizyczny Uniwersytetu Jagiellońskiego mieścił się od 4 marca 1912 r. przy ul. Gołębiej 13, w budynku wybudowanym w latach 1908-1911 dzięki staraniom dyrektora zakładu prof. Augusta Witkowskiego (1854-1913). W styczniu 1913 r. Senat Uniwersytetu Jagiellońskiego nadał budynkowi nazwę używaną do dziś: Collegium Witkowskiego ${ }^{27}$. Tam też, obok zaplecza naukowego zakładu, znajdowały się warsztat i służbowe trzypokojowe mieszkanie zakładowego mechanika ${ }^{28}$. Zamieszkiwał je Roman Calikowski wraz z rodziną. W listopadzie 1939 r. budynek został przejęty przez Urząd Powiernika Uniwersytetu Jagiellońskiego - powołany przez okupanta. Pierwszy kierownik urzędu, dr Friedrich Rolshoven,

17 AUJ, sygn. SII 620 Roman Calikowski, teczka osobowa, pismo Romana Calikowskiego do Powiatowej Komisji Uzupełnień Kraków-Miasto z dnia 23 /l 1932 r. Komenda i trzy bataliony pułku stacjonowały w Krakowie. W sierpniu 1914 r. pułk wchodził w skład 91 Brygady Piechoty Obrony Krajowej. W kwietniu 1917 r. pułk został przemianowany na 16 Pułk Strzelców „Kraków” (16 Schützen-Regimenter Krakau).

18 AUJ, sygn. SII 620 Roman Calikowski, teczka osobowa.

19 AUJ, sygn. SIl 620 Roman Calikowski, teczka osobowa, Dyplom nadania.

20 AUJ, sygn. SII 620 Roman Calikowski, teczka osobowa, pismo Ministerstwa Wyznań Religijnych i Oświecenia Publicznego nr 7281/IV/19 z dnia 19 X 1919 r. Mianowanie nastąpiło na wniosek Komitetu Organizacyjnego Akademii Górniczej w Krakowie.

21 AUJ, sygn. SIl 620 Roman Calikowski, teczka osobowa, pismo Rektora Akademii Górniczej nr 664/21 z dnia 6 VI $1921 \mathrm{r}$.

22 AUJ, sygn. SIl 620 Roman Calikowski, teczka osobowa, Wykaz stanu służby.

23 AUJ, sygn. SIl 620, pismo z dnia 4 II $1938 r$.

24 AUJ, sygn. SII 620 Roman Calikowski, teczka osobowa, zaświadczenie Izby Rzemieślniczej z dnia 27 VIII 1938 r. nr II.2114/38/OH.

25 AUJ, sygn. SII 620 Roman Calikowski, teczka osobowa, pismo podsekretarza Stanu w Warszawie, nr III Kwal $6587 / 38$ z dnia 28 XI 1938 r.

26 AUJ, sygn. SII 620 Roman Calikowski, teczka osobowa, pismo Konstantego Zakrzewskiego do Rektoratu UJ z dnia 15 IX 1938 r.

27 P. Franaszek, Collegium Witkowskiego, Kraków, 2014. Gmach dla potrzeb Collegium Physicum został wzniesiony według projektu Gabriela Niewiadomskiego.

28 Ibid., s. 47. 
zamieszkał w Collegium Witkowskiego w listopadzie 1939 r. $^{29}$ Powiernictwo oficjalnie zatrudniło Romana Calikowskiego jako nadzorcę odpowiedzialnego za stan techniczny budynku. Żona wraz z córką sprzątały budynek i przygotowywały posiłki dla jego mieszkańców ${ }^{30}$. Zadaniem Powiernictwa była formalna likwidacja Uniwersytetu Jagiellońskiego i jego zakładów. Akcję likwidacji mienia uniwersytetu rozpoczęto w maju 1940 r., Niszczono i rabowano wyposażenie pracowni i aparaturę z uniwersyteckich zakładów przyrodniczych. Roman Calikowski podejmował próby ratowania przyrządów Zakładu Fizycznego. W biogramie mechanika czytamy:

W czasie okupacji niemieckiej, gdy nadeszły ciężkie chwile dla Zakładu, wszystkie starania swoje obrócił dla ratowania przyrządów i majątku Zakładu. Ciągłe ukrywanie i przenoszenie przyrządów [...] nadszarpnęły jego zdrowie i doprowadziły do ataku serca i nagłej śmierci ${ }^{31}$.

Roman Calikowski zmarł 22 sierpnia 1940 r. Początkowo obowiązki ojca przejął Roman Julian. Uzyskał zgodę na tę pracę dzięki bardzo dobrej opinii o rodzinie, danej władzom Powiernictwa przez dr Friedricha Rolshovena ${ }^{32}$. Później kariera zawodowa Romana Juliana potoczyła się inaczej niż ojca.

Gdy Roman Calikowski rozpoczynał pracę na Uniwersytecie Jagiellońskim w 1904 r., było to już 21 lat po największych osiągnięciach naukowych Karola Olszewskiego i Zygmunta Wróblewskiego, tj. skropleniu tlenu, azotu i tlenku węgla w stanie statycznym w kwietniu 1883 r. Od 16 lat nie żył Zygmunt Wróblewski. W okresie pracy Romana Calikowskiego w Zakładzie Fizycznym (lata 1921-1940) Katedrę Fizyki Doświadczalnej UJ zajmował od 1917 r. prof. Konstanty Zakrzewski (1876-1948), a od roku 1935 Jan Weyssenhoff (1889-1972). Nie zachowały się przyrządy ani informacje o przyrządach, które Roman wykonywałby dla obu profesorów. Wiadomo natomiast, że we wcześniejszym okresie swej pracy wykonywał on aparaty kriogeniczne dla Karola Olszewskiego. Bezpośrednia współpraca Romana Calikowskiego z Karolem Olszewskim prawdopodobnie obejmowała krótki okres lat 1911-1915, tj. od czasu jego zatrudnienia jako mechanika w I Zakładzie Chemicznym do śmierci Karola Olszewskiego w marcu 1915 r. Prof. Karol Olszewski prowadził I Zakład Chemiczny od 1891 r. jako następca Emiliana Czyrniańskiego (1824-1888). Z okresu zawodowej aktywności Olszewskiego w zbiorach Uniwersytetu Jagiellońskiego zachowały się przyrządy badawcze, wykonane przez Romana Calikowskiego lub jemu przypisywane z pewnym prawdopodobieństwem. Jedynie jeden z nich jest sygnowany przez tego mechanika. O prawdopodobnej atrybucji pozostałych sądzić można po dacie ich wykonania, choć w tym samym czasie przyrządy do skraplania gazów wykonywał w Krakowie także Władysław Grodzicki. Tabliczką firmową "Roman Calikowski. Mechanik. Kraków ul. Jagiellońska 22" oznaczona jest skraplarka powietrza typu Hampsona

31 Relacje pracowników Uniwersytetu Jagiellońskiego o ich losach osobistych i dziejach uczelni w czasie drugiej wojny światowej, oprac. J. Michalewicz, Kraków 2005, s. 374.; AUJ, sygn. KHUW 19, Roman Calikowski, 14 IX 1945, biogram niepodpisany.

32 P. Franaszek, op. cit., s. 48. 


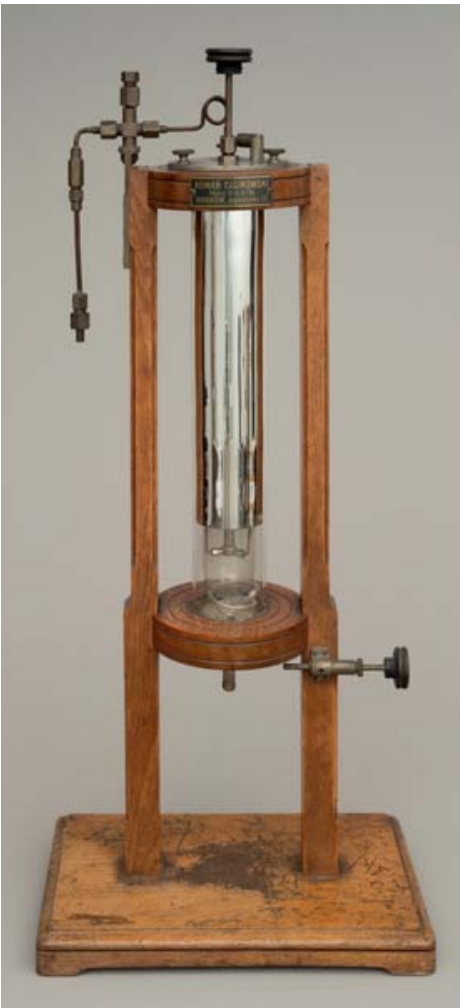

Ryc. 2. Przyrząd do demonstracji skroplenia powietrza podczas wykładu, konstrukcja wg Hampsona, proj. Karol Olszewski, wyk. Roman Calikowski, ok. 1911 r., wł. Muzeum UJ, nr in. MUJ 5183,1380/N, fot. Grzegorz Zygier.

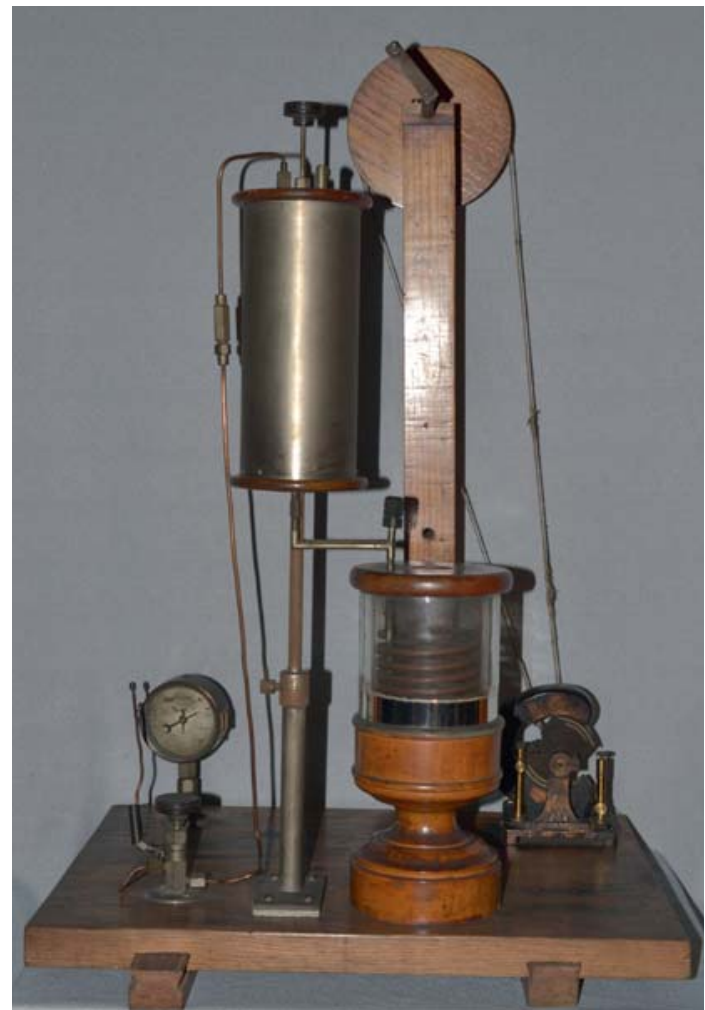

Ryc. 3. Kriostat do temperatur od $-190^{\circ} \mathrm{C}$ do $0^{\circ} \mathrm{C}$, proj. Karol Olszewski, wyk. Roman Calikowski (?), ok. 1912 r., wł. MUJ, nr in. 4478, 489/N, fot. Janusz Kozina.

datowana na rok $1911^{33}$. Model ten opisany został przez Karola Olszewskiego w 1902 r. $^{34}$ Był to prosty, niewielki aparat, jak określił go Olszewski, służący „do demonstracji skroplenia powietrza podczas wykładu"35.

Wiadomo, że Olszewski zakupił w 1899 r. dwa różnego typu przyrządy do skraplania gazów: przyrząd typu Hampsona i typu Lindego. Eksperymentując z oboma, krytycznie odniósł się do działania przyrządu wg Lindego ${ }^{36}$. Zachowana skraplarka sygnowana przez Romana Calikowskiego wykonana została przez mechanika na wzór przyrządu Hampsona, według wskazówek i modyfikacji Karola Olszewskiego.

$33 \mathrm{Nr}$ inw. MUJ 5183, 1380/V. Przyrząd wykonany został w okresie, gdy Roman Calikowski był zatrudniony w I Zakładzie Chemicznym, mieszczącym się wówczas pod adresem Jagiellońska 22.

34 K. Olszewski, Przyrządy do skroplenia powietrza i wodoru, „Rozprawy Wydziału Matematyczno-Przyrodniczego Akademii Umiejętności", Seria A, t. 2. Dział A, 1902, s. 457-470; D. Burczyk-Marona, H. Kuzyk, K. Olszewski, Z. Wróblewski. 100-lecie skroplenia tlenu. Katalog wystawy, Kraków 1983.

35 K. Olszewski, op. cit., s. 461.

36 Ibid., s. 457- 470; List do prof. Politechniki Warszawskiej Wiktora Biernackiego z dnia 24 XII 1900 r., w materiałach niezinwentaryzowanych przekazanych do Archiwum UJ przez dr hab. Elżbietę SzczepaniecCięciak, pudło nr 6 . 


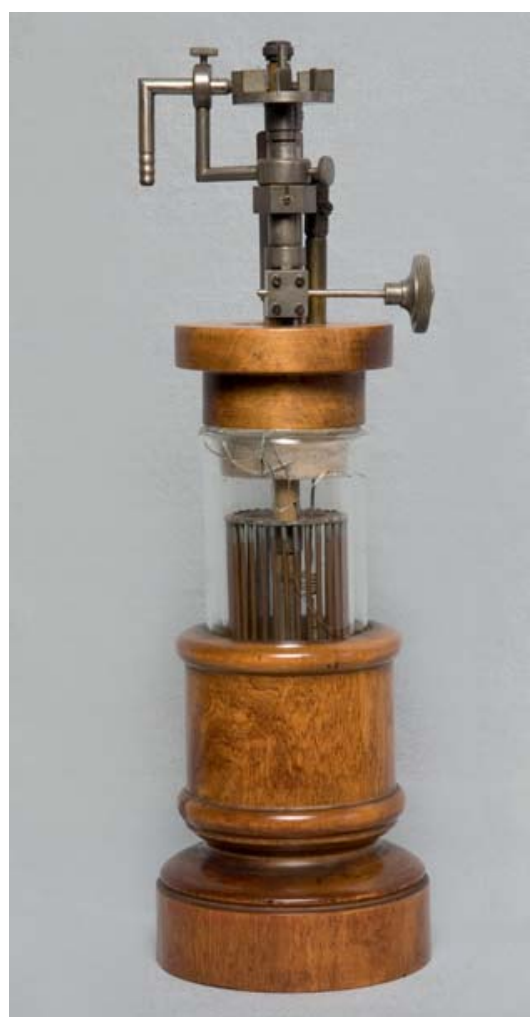

Ryc. 4. Kriostat do temperatur od $-250^{\circ} \mathrm{C}$ do $-190^{\circ} \mathrm{C}$, proj. Karol Olszewski, wyk. Roman Calikowski (?), ok. 1913 r., wł. MUJ, $n r$ in. 4627, 632/N, fot. Janusz Kozina.

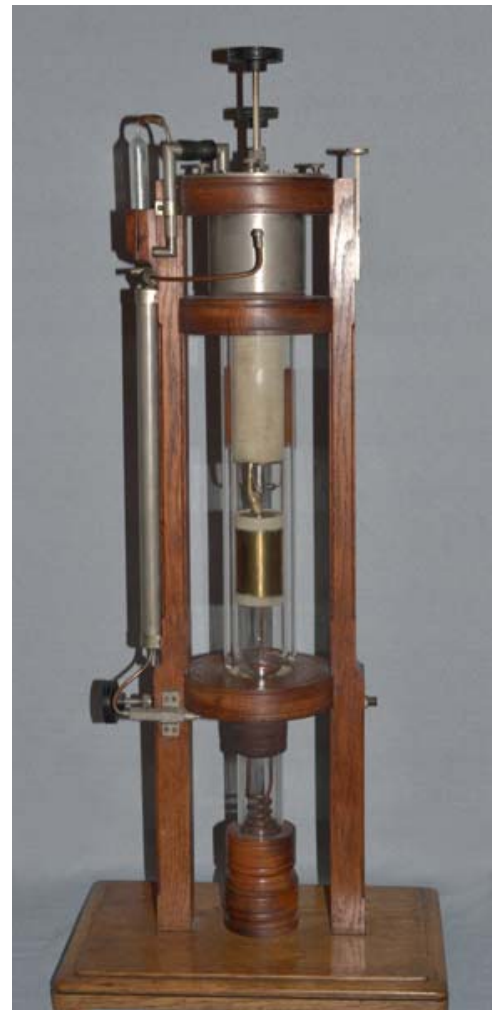

Ryc. 5. Aparat do rozdzielania składników powietrza w fazie ciekłej, proj. Karol Olszewski, ok. 1914 r.,wyk. Zakład Chemiczny UJ, Muzeum UJ, nr in. $4460,471 / \mathrm{N}$, fot. Janusz Kozina.

Pozostałe przyrządy, zachowane z lat współpracy Romana Calikowskiego z Karolem Olszewskim to dwa termostaty do utrzymywania niskich temperatur (kriostaty) oraz aparat do rozdzielania składników powietrza, czyli tlenu i azotu w fazie ciekłej.

Kriostat posiada układ termostatujący w zakresie od $-190^{\circ} \mathrm{C}$ do $0^{\circ} \mathrm{C}$, pozwalający utrzymać temperaturę z dokładnością do $0,5^{\circ} \mathrm{C}$. Aparat składa się z chłodzonego przeciwprądowo skraplacza powietrza w metalowej obudowie i naczynia Dewara z wężownicą wewnątrz, przez którą przepływa ciekłe powietrze. Naczynie wypełniane było medium chłodzącym, w zależności od wymaganej do badań temperatury. Osadzony w podstawie silniczek elektryczny służył do napędu niezachowanego mieszadła.

Drugi kriostat, o mniejszych rozmiarach, pozwalał na utrzymanie temperatury w zakresie od $-250^{\circ} \mathrm{C}$ do $-190^{\circ} \mathrm{C}$.

Medium chłodzącym było również ciekłe powietrze, w tej konstrukcji zasysane z zewnątrz, przeciwprądowo do spirali umieszczonej wewnątrz naczynia Dewara. Temperatura medium chłodzącego $w$ kriostacie kontrolowana była przez regulację ciśnienia odpompowywanego powietrza i mierzona termometrem oporowym.

Romanowi Calikowskiemu przypisać można również udział w wykonaniu ostatniego z przyrządów kriogenicznych zaprojektowanych przez Karola Olszewskiego. Był to apa- 


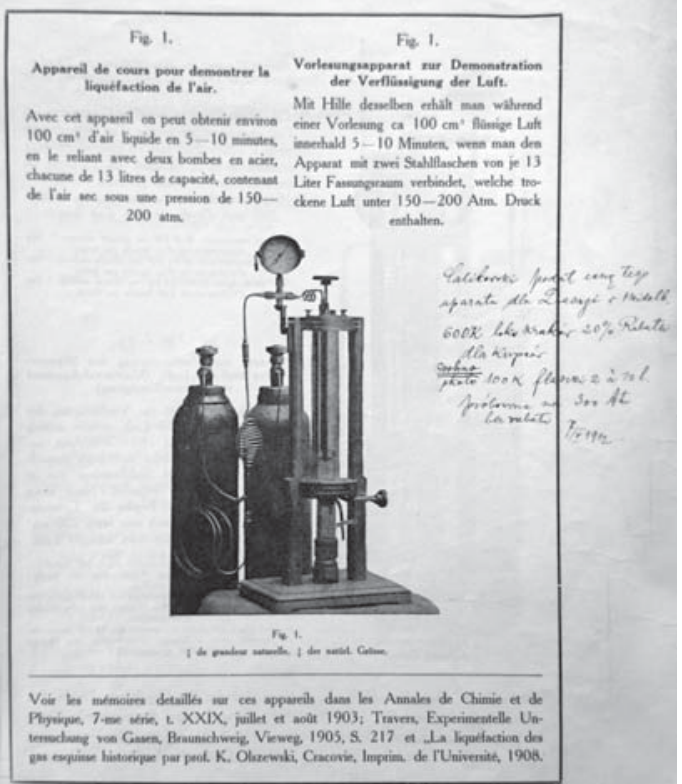

Ryc. 6. Strona z folderu reklamowego przyrządów do skraplania gazów wykonywanych przez Władysława Grodzickiego z odręczną adnotacją Karola Olszewskiego, AUJ, materiały nieopracowane, pudło $\mathrm{nr} 1$, reprod. Ewa Wyka. rat do rozdziału ciekłych gazów: tlenu i azotu z powietrza. Datowany na rok 1915, aparat nie został już przez Olszewskiego opisany i opublikowany, jak to czynił uczony każdorazowo z nową swą konstrukcją. Olszewski, wówczas już bardzo chory, był u kresu swego życia.

Roman Calikowski, podobnie jak mechanik Władysław Grodzicki, realizował zamówienia na aparaty do skraplania gazów. Wiadomo, że u niego zamówione zostały skraplarki do Kaiser Wilhelm Institut w Berlinie, uniwersytetów w Madrycie, Chicago, Bombaju ${ }^{37}$. Na jednym z egzemplarzy folderu przyrządów do skraplania gazów, reklamującym aparaty Władysława Grodzickiego znajduje się odręczna nota Karola Olszewskiego z 1912 r. dotycząca ceny proponowanej przez Romana Calikowskiego za przyrząd demonstracyjny do skraplania powietrza ${ }^{38}$.

Roman Calikowski wykonywał skraplarki gazów być może jeszcze po śmierci Karola Olszewskiego. W kwietniu 1922 r. prezentował je na wystawie przyrządów fizycznych w pawilonie fizycznym Uniwersytetu Warszawskiego ${ }^{39}$. Po nagłej śmierci Romana tradycje rodzinne na Uniwersytecie Jagiellońskim kontynuowali jego brat Ludwik i syn Roman Julian.

Ten ostatni używał tylko imienia Roman lecz dla jasności tekstu używać się będzie obu imion - Roman Julian - mówiąc o Romanie synu.

\section{Ludwik Calikowski}

Z krakowską uczelnią związany był również młodszy o 10 lat brat Romana - Ludwik Calikowski. Urodzony w Krakowie 2 sierpnia 1896 r., poślubił Marię z Kluzeków (1900-1995) zamieszkałą w Prądniku Białym. Małżeństwo miało troje dzieci: najstarszą Władysławę (1921-1998), Jana (1924-1997) i najmłodszego Adama (1930-2013)

37 Nie udało się jak dotychczas odnaleźć dokumentów potwierdzających zamówienia złożone przez powyższe instytucje u Calikowskiego. Informacje pośrednio pozyskane: patrz relacja AUJ, sygn. KHUW 19, Roman Calikowski, 14 IX 1945 r., biogram niepodpisany.

38 Folder w materiałach niezinwentaryzowanych w Archiwum UJ, przekazanych przez dr hab. Elżbietę Szczepaniec-Cięciak, pudło nr 6.

39 Przegląd Techniczny nr 17 z dnia 25 IV 1922. Wystawa miała miejsce dnia 19 IV1922 r. w Pawilonie Fizycznym Uniwersytetu Warszawskiego przy ul. Hożej 69.

40 AUJ, sygn. SII 620 Ludwik Calikowski, teczka osobowa, ślub 24 XI 1920 r., Wykaz stanu służby. 


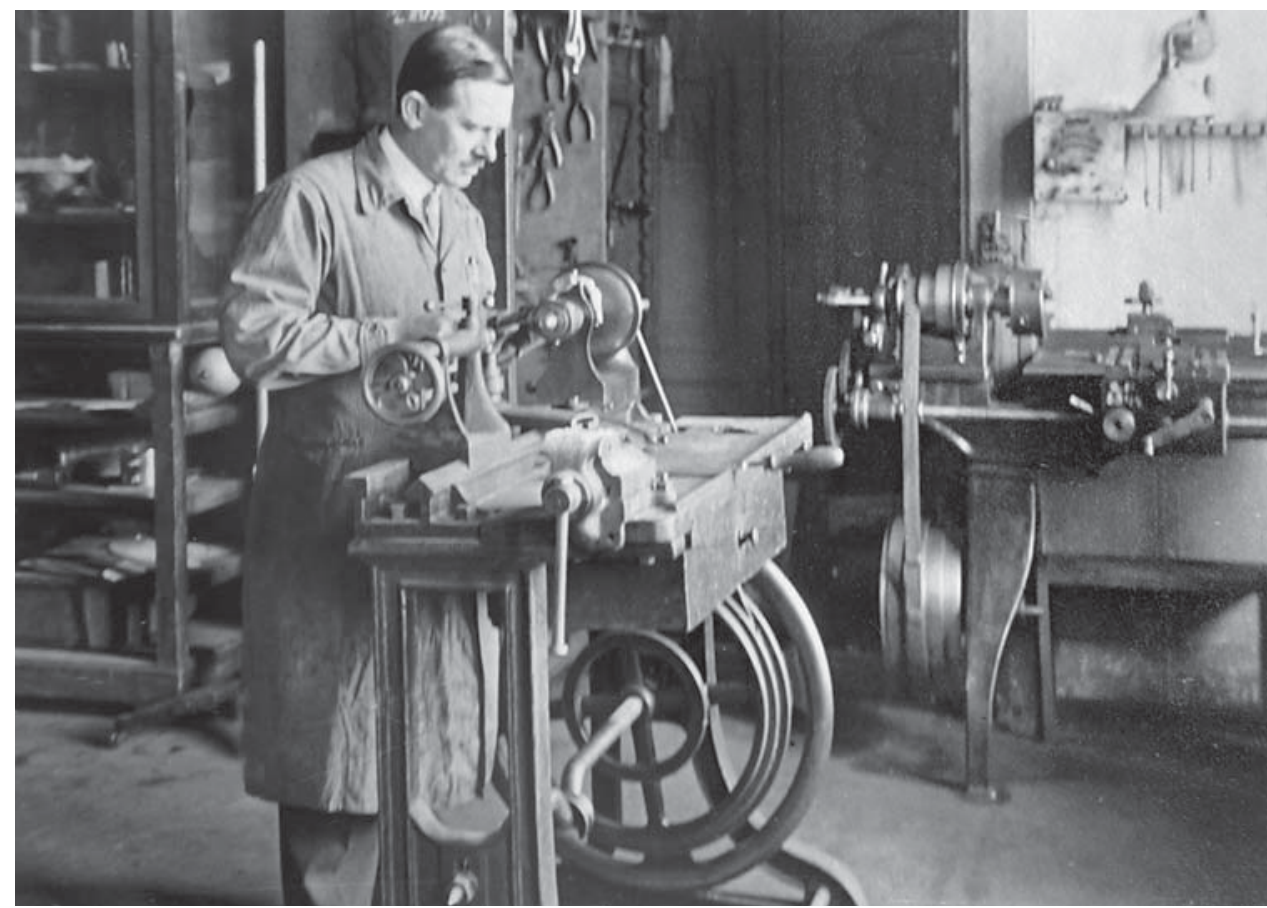

Oे

Ryc. 7. Roman Calikowski przy pracy, 1938 r. wł., Maria Magdalena Calikowska, reprod. Ewa Wyka.
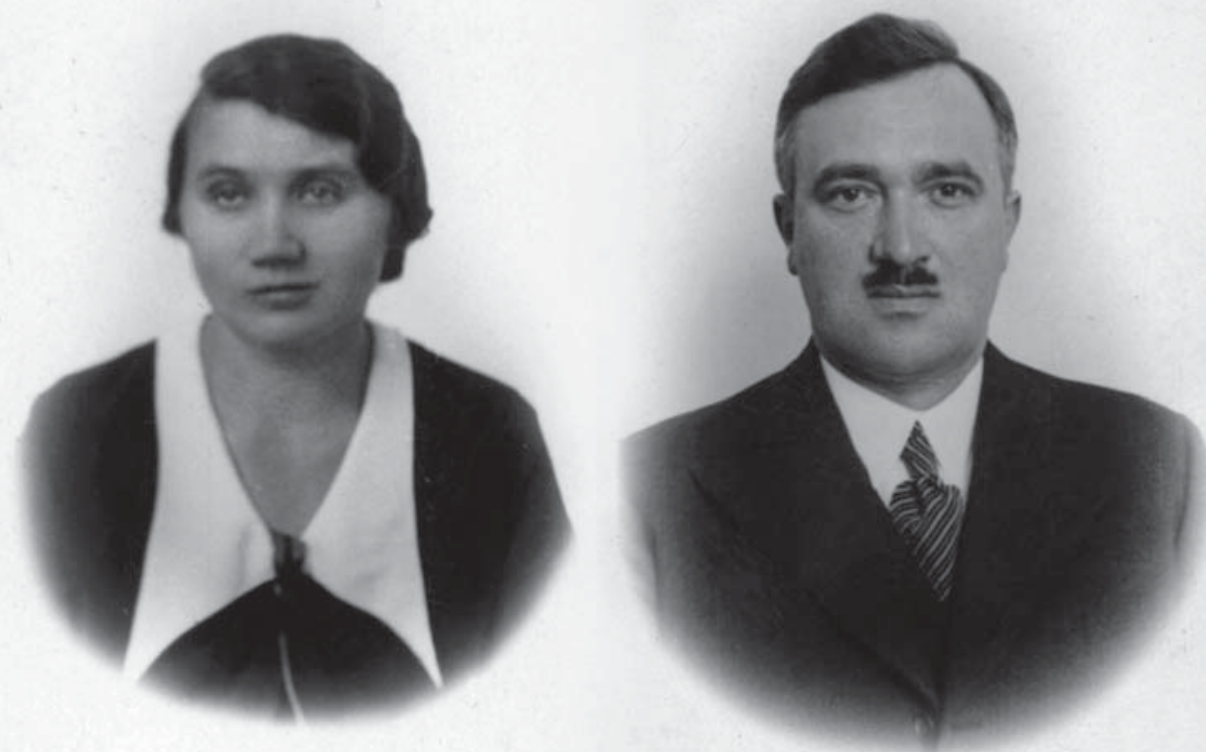

Ryc. 8. Maria i Ludwik Calikowscy, AUJ, sygn. SII 620, Ludwik Calikowski, teczka osobowa, fot. AUJ. 


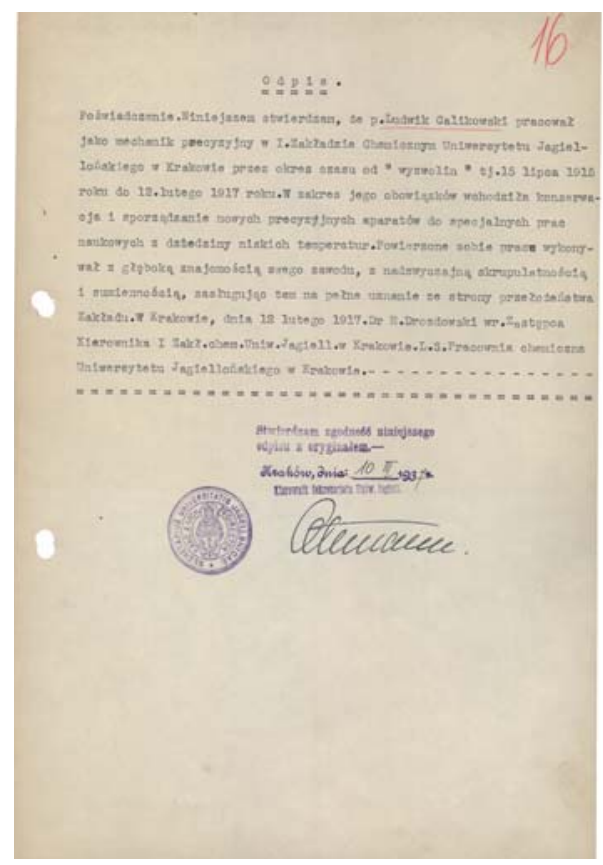

Ryc. 9. Poświadczenie o pracy Ludwika Calikowskiego w Zakładzie Chemicznym UJ i o jej zakresie, AUJ, SII 620 Ludwik Calikowski, teczka osobowa, k.16, fot. Arch. UJ.

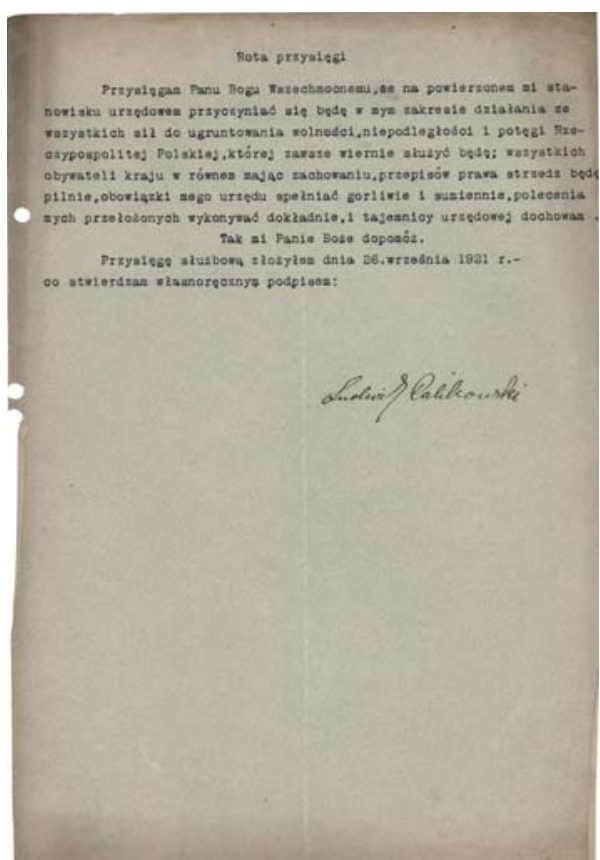

Ryc. 10. Rota przysięgi złożonej przez Ludwika Calikowskiego z chwilą rozpoczęcia pracy na UJ, 26 września 1921 r., AUJ SII 620 Ludwik Calikowski, teczka osobowa, fot. AUJ.

Ludwik ukończył 3 klasy Szkoły Wydziałowej Męskiej w Krakowie im. św. Mikołaja (1912 r.) i 2 klasy Państwowej Szkoły Przemysłowej Zawodowej Szkoły Uzupełniającej $(1914 \text { r. })^{41}$. W 1915 r. zdał egzamin czeladniczy i uzyskał dyplom czeladnika wystawiony przez Stowarzyszenie Przemysłowe Mechaników, Rytowników i Optyków w Krakowie ${ }^{42}$. Po wyzwoleniu na czeladnika podjął pracę na okres dwóch lat w I Zakładzie Chemicznym UJ (15 lipca 1915-15 lutego 1917) znajdującym się wówczas przy ul. Jagiellońskiej 22 (obecnie ul. Olszewskiego 2). Praktykował tam u swego brata Romana.

Odbył również praktykę jako mechanik precyzyjny w fabryce aparatów fotograficznych firmy Goldman w Wiedniu43. Po kilkuletniej służbie wojskowej, z dniem 1 czerwca w 1921 r., powrócił do pracy jako mechanik w I Zakładzie Chemicznym UJ, kolejno awansując na stanowisko starszego funkcjonariusza technicznego (1931-1937) i starszego mechanika ${ }^{44}$.

W roku 1928 nagrodzony został Medalem Dziesięciolecia Odzyskanej Niepodległości45, a później brązowym i srebrnym medalem (1938 r., 1939 r. ) za długoletnią pracę ${ }^{46}$.

41 AUJ, sygn. SII 620 Ludwik Calikowski, teczka osobowa, k. 8, 11.

42 AUJ, sygn. SII 620 Ludwik Calikowski, teczka osobowa, k. 12.

43 AUJ, sygn. SII 620 Ludwik Calikowski, teczka osobowa, pismo nr K/24/623/56.

44 AUJ, sygn. SII 620 Ludwik Calikowski, teczka osobowa, k. 17, zatrudnienie jako mechanika w 1921 r. i awans na starszego mechanika, k. 26. W latach 1917-1918 odbywał służbę w wojsku austriackim w 5 dywizjonie samochodowym, a po odzyskaniu niepodległości w wojsku polskim (1919-1921), AUJ, SII 620 Ludwik Calikowski teczka osobowa, k.13.

45 AUJ, sygn. SII 620 Ludwik Calikowski, teczka osobowa, pismo Rektora UJ z dnia 28 XII 1928 r.

46 AUJ, sygn. SIl 620 Ludwik Calikowski, teczka osobowa, oryginały dyplomów. 
Dnia 3 września 1939 r. został powołany do Il pułku lotniczego w Krakowie i w stopniu sierżanta brał udział w kampanii wrześniowej. Wraz z pułkiem dnia 18 września 1939 r. przekroczył granicę rumuńską i został internowany. Zwolniony w lipcu 1940 r. wrócił do Krakowa i od sierpnia podjął pracę (1940-1945) jako mechanik w Szkole Przemysłowej. Mieściła się ona w tym samym budynku co I Zakład Chemiczny przy ul. Jagiellońskiej 22. Calikowski pracował praktycznie na potrzeby Zakładu Chemicznego. W okresie okupacji niemieckiej zajmował się konserwacją przyrządów, także kriogenicznych ${ }^{47}$.

W swym wspomnieniu z czasów II wojny światowej pisze:

Część z tych przyrządów konserwowanych przez mnie w czasie okupacji niemieckiej jak akumulatory, kompresory, motory, urządzenia do skraplania powietrza przechowały się w nienaruszonym stanie i już są użyte do pracy w uczelni ${ }^{48}$.

Jak pisze prof. Wiktor Jakób (1886-1971), kierownik Katedry Chemii Nieorganicznej UJ w latach 1950-1960: „Dzięki niemu udało się w czasie okupacji rozmontować i ukryć najcenniejszy przyrząd - kompresor wodorowy - służący w laboratorium niskich temperatur do skraplania gazów"49. W 1957 r. Ludwik Calikowski został przekwalifikowany na stanowisko asystenta technicznego przy Katedrze Chemii Nieorganicznej UJ50. Nie zachowały się szczegółowe informacje, jakie przyrządy wykonał on podczas swej długoletniej pracy. Bazować można jedynie na pozostałych dokumentach i fotografiach. Prof. Wiktor Jakób, wystawił mu bardzo dobrą opinię:

Ob. Calikowski, długoletni pracownik tutejszego Zakładu, wykonał cały szereg aparatów naukowych przy czym wykazał w tym kierunku nie tylko uzdolnienie ale także umiejętność samodzielnego konstruktora"51.

Okres pracy Ludwika Calikowskiego na Uniwersytecie Jagiellońskim przypada na czasy prowadzenia I Zakładu Chemicznego UJ przez prof. Tadeusza Estreichera (1871-1952) w latach 1919-1948 i jego następcy - właśnie prof. Wiktora Jakóba. Tematyka badań obu profesorów była różna. Wiktor Jakób tworzył polską szkołę chemii koordynacyjnej, Tadeusz Estreicher kontynuował m.in. prace z zakresu kriogeniki. Nie są znane przyrządy wykonane przez Ludwika Calikowskiego dla Wiktora Jakóba. Wiadomo zaś, że zaangażowany był on w odbudowę pracowni niskich temperatur prowadzoną przez Tadeusza Estreichera ${ }^{52}$. Wyposażenie pracowni odnawiane było dwukrotnie. Po raz pierwszy, około 1936 r., z Funduszu Wieczystego im. Karola Olszewskiego zrekonstruowano urządzenia do skraplania wodoru, unowocześniono instalację, zakupiono nowy kompresor wodo-

47 AUJ, sygn. KHUW 11 Ludwik Calikowski, rękopis biogramu z dnia 27 IV 1945 r.

48 AUJ, sygn. KHUW 11 Ludwik Calikowski, rękopis biogramu z dnia 27 IV 1945 r.

49 AUJ, sygn. SII 620 Ludwik Calikowski, teczka osobowa, pismo prof. W. Jakóba do Oddziału Kadr UJ z dnia 1 / $1956 r$.

50 AUJ, sygn. SII 620 Ludwik Calikowski, teczka osobowa, pismo K24/432/57.

51 AUJ, sygn. SII 620 Ludwik Calikowski, teczka osobowa, pismo z dnia 20 XI 1956 r.

52 A. Samotus, Wiktor Jakób (1886-1971) Chemik organik [w:] Złota księga Wydziału Chemii, t. 1, red. E. Szczepaniec-Cięciak, Kraków 2000, s. 225-230; E. Szczepaniec-Cięciak, Tadeusz Estreicher (1871-1952) Chemik, kriogenik, historyk i popularyzator nauki, publicysta, organik [w:] Złota księga Wydział Chemii, t. 1, red. E. Szczepaniec-Cięciak, Kraków 2000, s.183-191. 


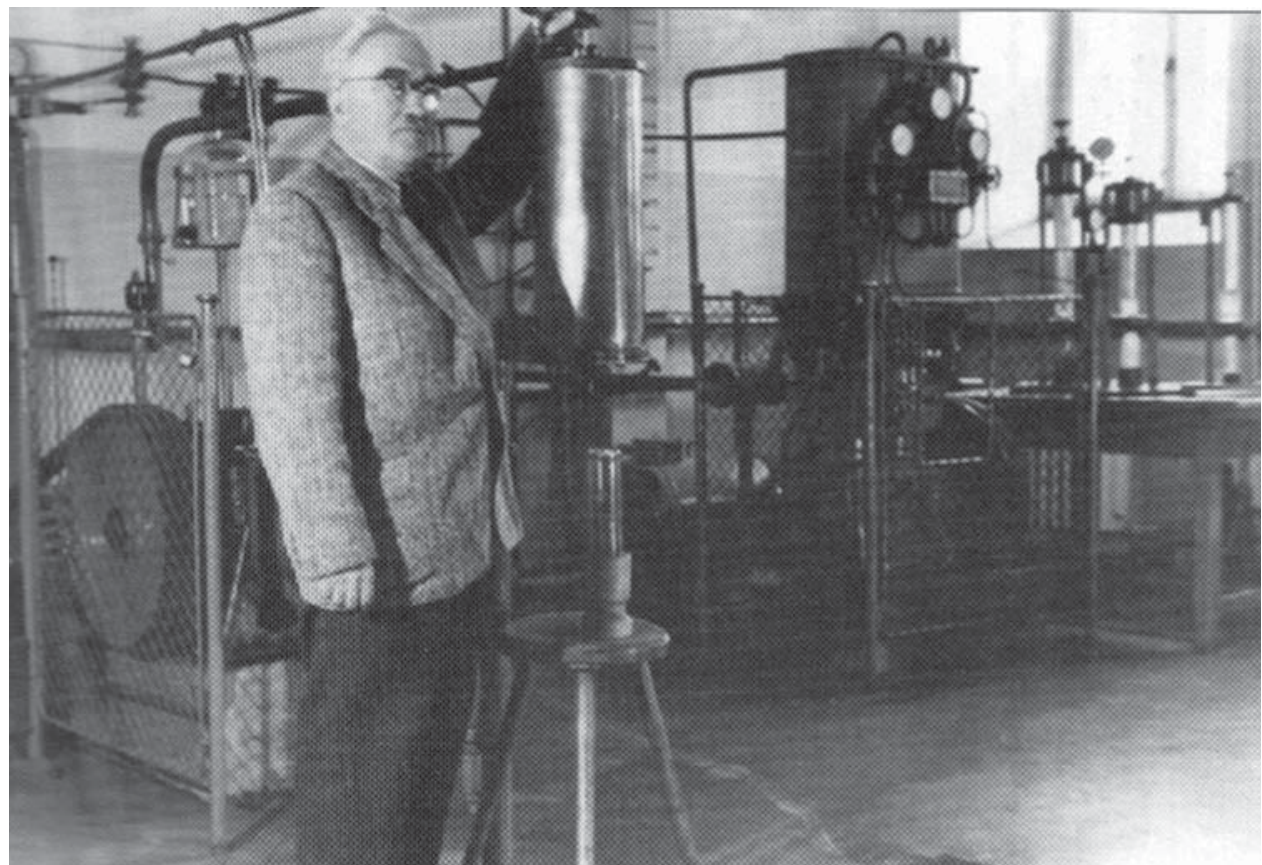

Ryc. 11. Ludwik Calikowski przy skraplarce powietrzno-azotowej w budynku Instytutu Chemii UJ przy ul. Krupniczej 41 (obecnie ul. R. Ingardena 3), ok.1960 r., Złota Księga Wydziału Chemii, t. 1, red. Elżbieta Szczepaniec-Cięciak, Kraków 2000, s. 357.

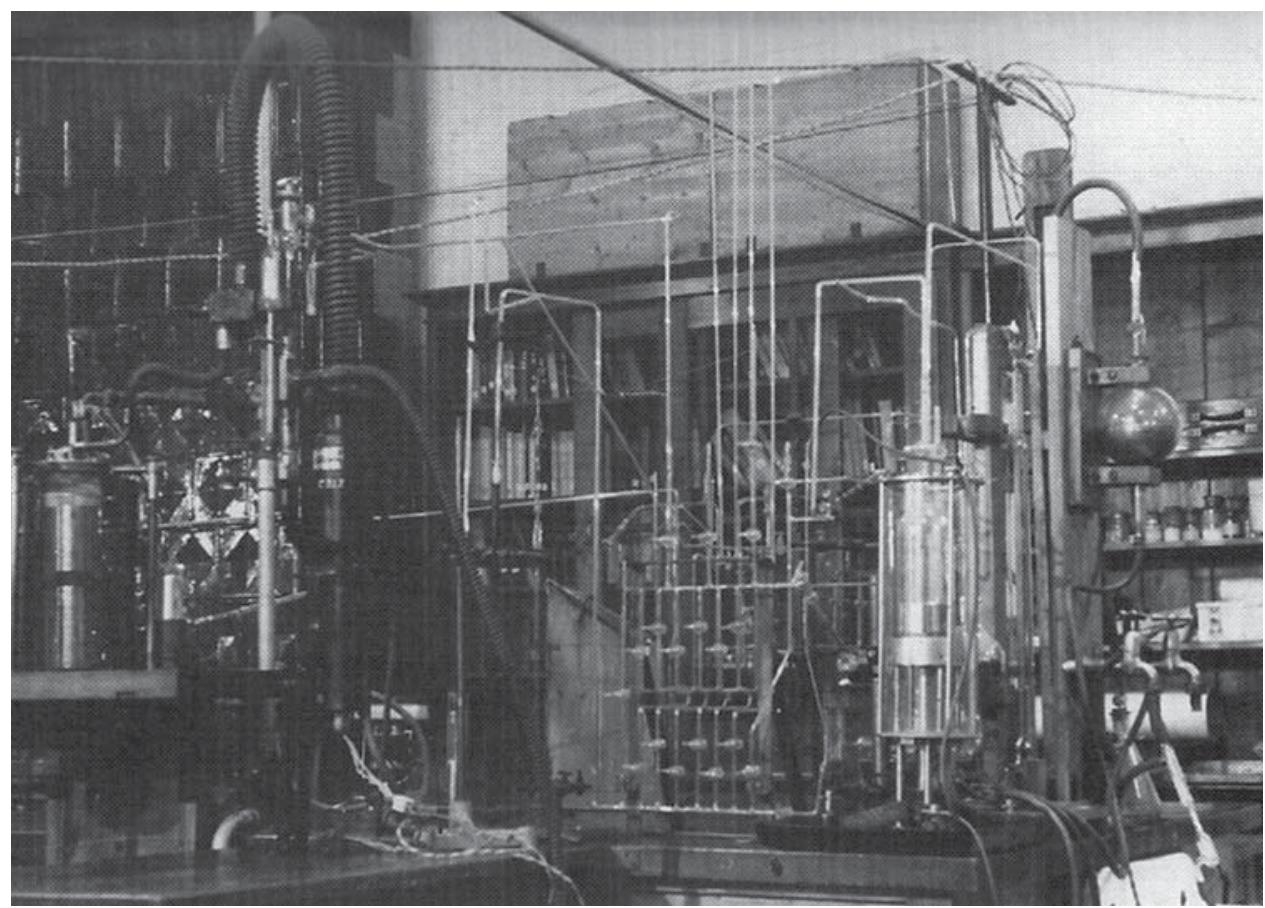

Ryc. 12. Aparatura zbudowana przez E. Kurzyńca do badań kalorymetrycznych układów złożonych z zestalonych gazów w pracowni I Zakładu Chemicznego UJ przy ul. Olszewskiego 2 w Krakowie, ok. 1950 r., fot. M. Dyrek, Złota Księga Wydziału Chemii, t. 1, red. E. Szczepaniec-Cięciak, Kraków 2000, s. 296. 
rowy firmy Reavell. Prace te realizowali, obok Tadeusza Estreichera, ówczesny adiunkt dr Edmund Kurzyniec (1902-1951) oraz Ludwik Calikowski53. Po 1945 r. Ludwik ponownie włączony został w prace nad uruchomieniem pracowni niskich temperatur ${ }^{54}$. Do skraplania powietrza i azotu stosowano wówczas skraplarkę skonstruowaną jeszcze przez jego brata Romana, a do skraplania wodoru przyrząd wykonany przez Karola Olszewskiego. Były to urządzenia dobrze znane mechanikowi.

Z dużym prawdopodobieństwem można sądzić, iż wykonywał on również aparaturę dla Edmunda Kurzyńca, który we wczesnym okresie kariery naukowej prowadził badania niskotemperaturowe ${ }^{55}$.

Ludwik Calikowski zmarł 8 kwietnia 1961 r., podobnie jak jego brat, na atak serca. Pochowany został w Krakowie na Cmentarzu Rakowickim.

\section{Roman Julian Calikowski}

Roman Julian Calikowski urodził się w Krakowie 26 lutego 1915 r. jako syn Walerii i Romana Calikowskich.

W roku akademickim 1933/1934 rozpoczął studia na Wydziale Górniczym Akademii Górniczej w Krakowie, gdzie uzyskał stopień doktora ${ }^{56}$. Wytwórczość w obszarze mechaniki precyzyjnej to stosunkowo krótki, nieco ponad dziesięcioletni okres w karierze naukowej Romana Juliana. Po śmierci ojca prowadził jego warsztat mechaniczny. Pod własnym szyldem otworzył firmę w 1937 r. początkowo pod adresem Kraków ul. Dietla 33, a następnie przy ul. Grodzkiej $62^{57}$. Na przyrządach, czy w zachowanych dokumentach znajdują się różne jej nazwy, jak "Wytwórnia przyrządów inż. R. Calikowski", "R. Calikowski mechanik precyzyjny” czy „R. Calikowski/ Kraków”, Warsztat Mechaniki

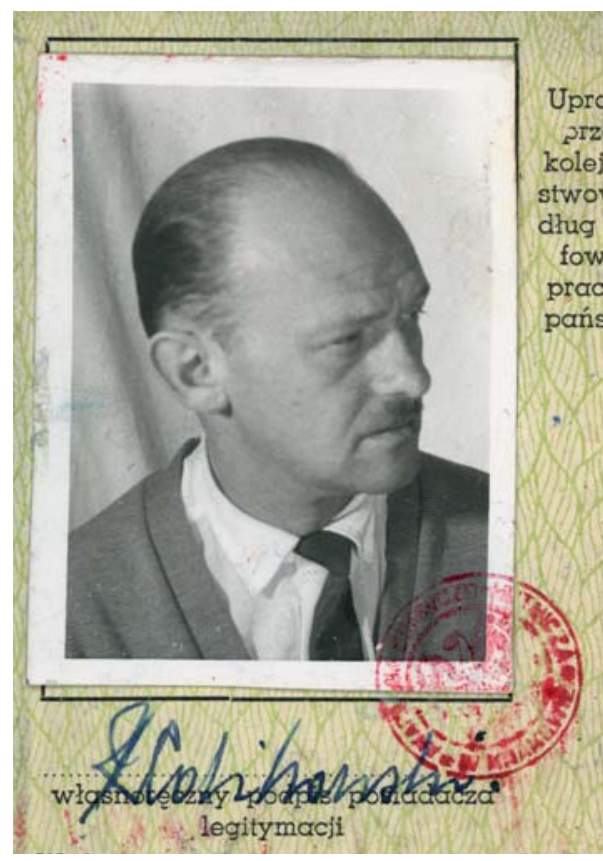

Ryc. 13. Roman Julian Calikowski, wł. Anna Calikowska, reprod. Ewa Wyka.

53 Eadem, Edmund Kurzyniec (1902-1951) Chemik kriogenik, [w:] Złota Księga Wydziału Chemii, t. 1, red. E. Szczepaniec-Cięciak, Kraków 2000, s. 291-304.; T. Estreicher, "llustrowany Kurier Codzienny”, nr 55 (24 II 1936).

54 E. Szczepaniec-Cięciak, Edmund Kurzyniec, s. 293.

55 Ibid.

56 AUJ, sygn. SII. 260 Roman Calikowski, teczka osobowa, zaświadczenie Rektoratu Akademii Górniczej z dnia 27 XI 1933 r., Temat pracy doktorskiej: Analiza konstrukcji stojaków metalowych przy eksploatacji ścianowej, rozpatrywana ze względu na współpracę z górotworem.

57 W Rejestrze Zakładów Przemysłowych i Rzemieślniczych pod nr 454 w roku 1943 figuruje jako właścicielka zakładu matka Romana Juliana Waleria Calikowska, wdowa po Romanie. Arch. Miasta Krakowa [Arch.M.Kr.], sygn. ZMKr 577. Zakład liczył wówczas 11 pracowników, w tym 6 uczniów. W rodzinnych zbiorach p. Marii Magdaleny Calikowskiej, córki Romana Juliana, znajduje się księga przychodów i rozchodów firmy prowadzona przez Walerię Calikowską. 


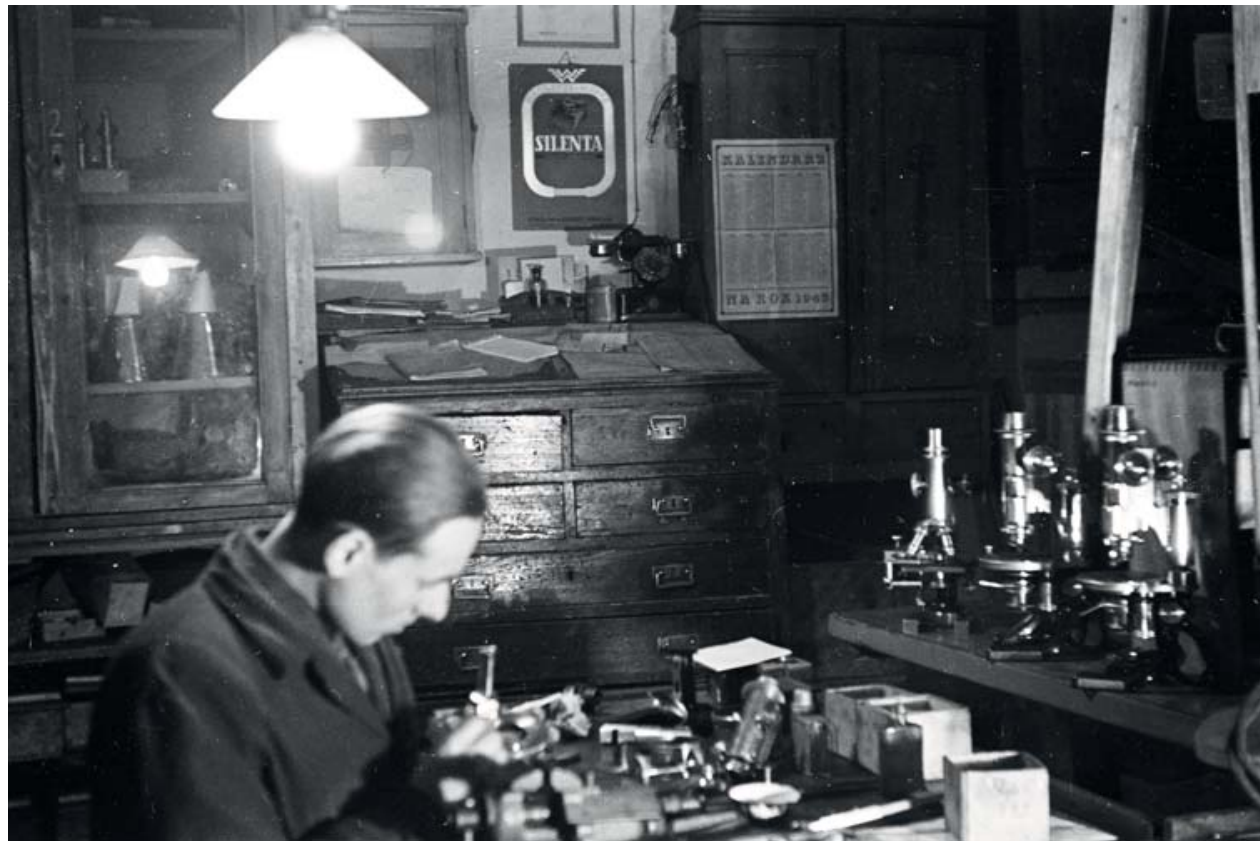

Ryc. 14a. Roman Julian Calikowski w warsztacie, Fundacja Ośrodka KARTA, zesp. OK_0910_0001_0001.

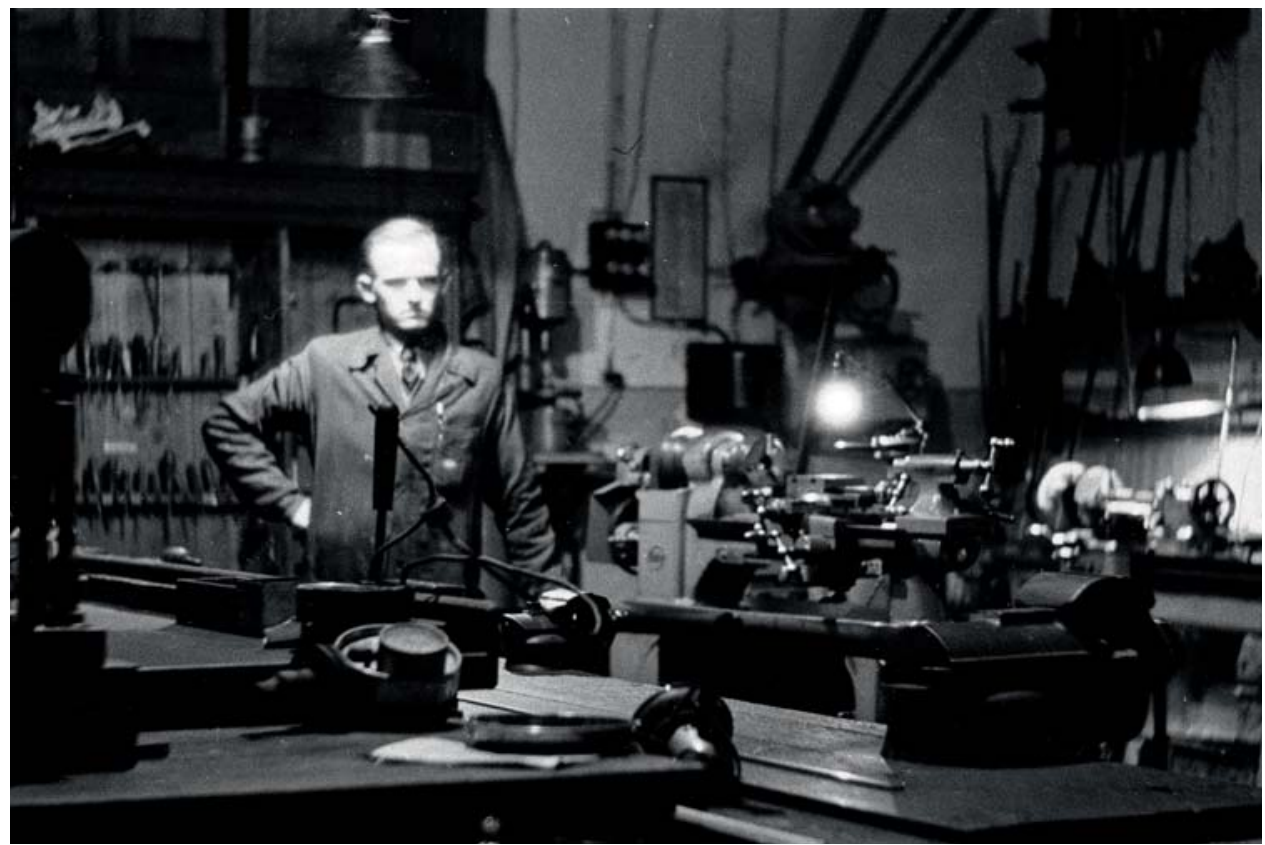

Ryc. 14b. Pracownik w warsztacie Romana Juliana Calikowskiego, 1945 r., Fundacja Ośrodka KARTA, zesp. OK 091000010001. 


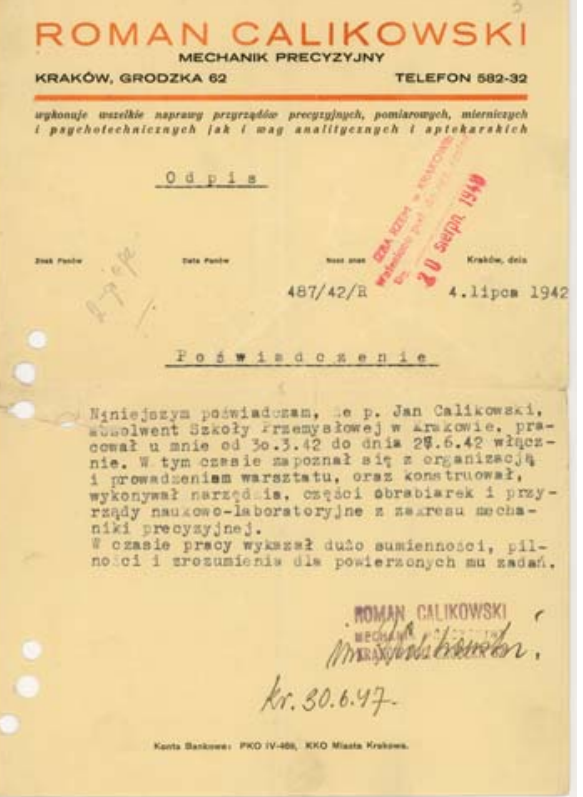

Ryc. 15. Papier firmowy pracowni Romana Juliana Calikowskiego, wł. Anna Calikowska, reprod. Ewa Wyka.

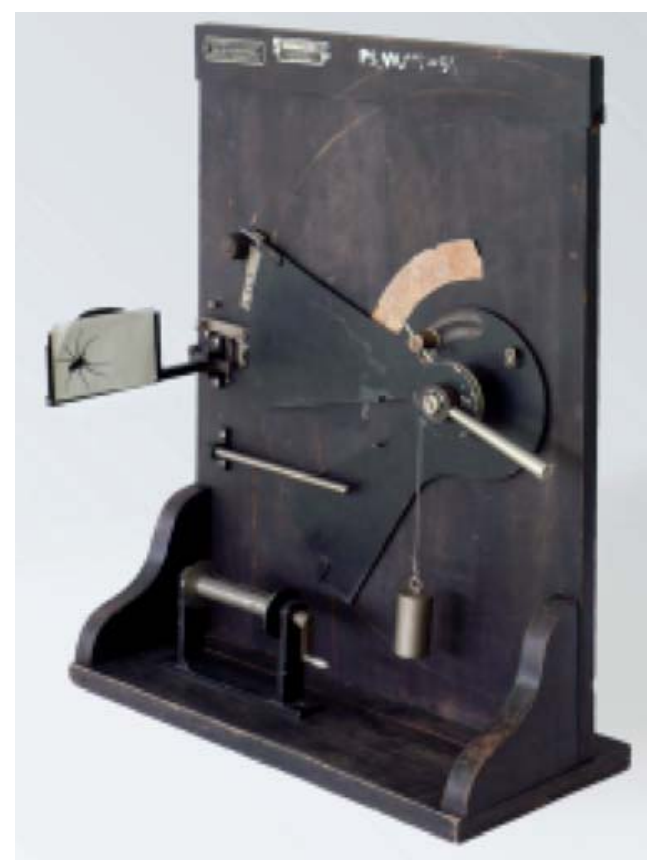

Ryc. 16. Tachistoskop Nieczajewa, „Wytwórnia inż. R. Calikowskiego", Kraków, przed 1950 r., wł. Instytut Psychologii Uniwersytetu Adama Mickiewicza w Poznaniu, fot. J. Zydorowicz.

Precyzyjnej ${ }^{58}$. W rodzinnych zasobach córki Marii Magdaleny Calikowskiej przechowywane są materiały świadczące, że w funkcjonowaniu wytwórni pomagała matka Waleria Calikowska. Prowadziła ona sprawy administracyjne. Firma, pod nazwą „R. Calikowski. Mechanik precyzyjny", została zamknięta przez właściciela z dniem 31 grudnia 1950 r.59 Od 15 stycznia 1951 r. maszyny i urządzenia użytkowane były przez Zakład Badawczy przy Katedrze Górnictwo II Akademii Górniczo-Hutniczej w Krakowie. Zgodnie z Rozporządzeniem Rady Ministrów z dnia 31 marca 1951 r. o przymusowym wykupie nieczynnych maszyn, warsztat Romana Juliana został formalnie wykupiony 20 maja 1952 r. przez Akademię Górniczo-Hutniczą za kwotę 17065 zł. ${ }^{60} \mathrm{~W}$ procedurze przymusowego wykupu niezbędne było potwierdzenie własności przejmowanych urządzeń. Świadkami w sprawie Romana Juliana byli jego stryjeczny brat Jan Calikowski i Stanisław Tyka ${ }^{61}$. Jan Calikowski (syn Ludwika) stwierdził, iż Roman Julian Calikowski przejął część maszyn z zakładu ojca, pozostałe zakupił. Jego zeznania potwierdził Stanisław Tyka, który pracował w warsztacie Romana Calikowskiego, a od 1937 r. u Romana Juliana ${ }^{62}$. Protokół przejęcia urządzeń pozwala sądzić o poziomie

58 Arch.M.Kr. Miejski Zarząd Przemysłu w Krakowie, sygn. 29/1186/351.

59 Arch.M.Kr. Miejski Zarząd Przemysłu w Krakowie sygn. 29/1186/351, Pismo Romana Juliana Calikowskiego do Wojewódzkiej Rady Narodowej w Krakowie z Warszawy z dnia 1 XI 1951 r.

60 Arch.M.Kr. Miejski Zarząd Przemysłu w Krakowie sygn. 29/1186/351, Protokół wraz z wykazem maszyn i ich wyposażeniem z dnia $20 \mathrm{~V} 1952 \mathrm{r}$.

61 Nie znaleziono bliższych informacji o tym pracowniku firmy.

62 Arch.M.Kr. Miejski Zarząd Przemysłu w Krakowie sygn. 29/1186/351, Protokół z dnia 12 IV 1952 r. 
wyposażenia warsztatu. Były to urządzenia produkcji firm zachodnich. Podstawowy sprzęt w warsztacie stanowiły 4 tokarki, w tym tokarka precyzyjna niemieckiej firmy G. Boley ${ }^{63}$, oraz tokarki firm: Leinen, Herbert, francuska tokarka rewolwerowa „Enr. Tenneris, Paris”, niemiecka maszyna podziałowa „z Kassel” do nacinania podziałek liniowych, „ze stołem obrotowym do okręgów i z pantografem do rysowania cyfr z szablonem", szlifierka, dwie wiertarki stołowe i liczne oprzyrządowanie niezbędne do pracy tych maszyn ${ }^{64}$.

W wyposażeniu warsztatu szczególnie zwraca uwagę maszyna do nacinania podziałek: liniowej i kątowej. Dawała ona możliwości wykonywania precyzyjnych skal urządzeń pomiarowych.

Szerszej kwerendy wymagałaby pełna odpowiedź na pytanie o sferę działalności i rodzaj przyrządów, jakie wykonywane były w „Wytwórni inż. R. Calikowskiego”. Dostępne na tym etapie badań materiały archiwalne ukazują różnorodność firmowej wytwórczości. Pewna grupa przyrządów zachowała się do dziś. W Instytucie Psychologii Uniwersytetu Adama Mickiewicza w Poznaniu znajdowały się dwa przyrządy psychotechniczne sygnowane przez inż. Romana Calikowskiego ${ }^{65}$. Wykonywanie tych przyrządów uznawał Roman Julian za jedną ze swych specjalności, co zaznaczył w papierze firmowym.

Wyjaśnieniem, skąd przyrządy krakowskiego mechanika znalazły się w Poznaniu może być fakt, iż w latach trzydziestych XX w. z Wydziałem Humanistycznym Uniwersytetu Poznańskiego, na którym ulokowana była psychologia, związany był dr inż. Bronisław Biegeleisen-Żelazowski (1881-1963)66. Założył on w Krakowie w 1920 r. Instytut Psychotechniczny, którym kierował do 1939 r. Był również kierownikiem pracowni psychotechnicznej przy Muzeum Przemysłowym w Krakowie ${ }^{67}$. Być może właśnie za jego pośrednictwem dwa przyrządy psychotechniczne znalazły się w Poznaniu. Są to tachistoskop typu Nieczajewa oraz aparat Piórkowskiego. Tachistoskop to przyrząd stosowany $w$ badaniach szybkości reakcji, poziomu skupienia, podzielności uwagi i wpływu różnych bodźców na te wielkości. Aparat zbudowany był w ten sposób, że obserwowany obraz pozostawał w polu obserwacji badanego przez krótki, określony czas, który można było regulować i mierzyć. Tachistoskop wg Aleksandra P. Nieczajewa (1870-1948) rosyjskiego psychologa i psychoneurologa, określano jako tachistoskop szkolny i stosowany był m.in. w badaniach zakresu uwagi dzieci68.

Drugi przyrząd do badań psychotechnicznych wykonany w pracowni inż. Romana Calikowskiego to tzw. aparat Piórkowskiego ${ }^{69}$. To jeden z pierwszych typów aparatów psychologicznych. Służył on do badania szybkości reakcji psychomotorycznej na proste bodźce emitowane w tempie narzuconym, do badania koordynacji wzrokowo-ruchowej ${ }^{70}$.

63 G. Boley - niemiecka firma założona w 1870 r. produkująca szeroki asortyment obrabiarek, poczynając od precyzyjnych do dużych urządzeń, www.lathes.co.uk/boley [dostęp 23.05.2018].

64 Arch.M.Kr. Miejski Zarząd Przemysłu w Krakowie sygn. 29/1186/351, Protokół z dnia 12 IV 1952 r.

65 A. Pankalla, A. Gołębiewska, Urządzenia psychotechniczne Instytutu Psychologii w Poznaniu z lat 1915-2005. Katalog wystawy pt. Gabinet psychotechniczny, Poznań 2009.

66 A. Wodecka-Hyjek, Wspomnienie Bronisława Biegeleisena-Żelazowskiego, „Organizacja i kierowanie”, 2013, $\mathrm{nr}$ 4(157), 169-174.

67 „Rzeczy piękne”, 1927, nr 9, s. 158

68 T. Jaroszyński, Metody badań psychologicznych w szkole, Warszawa 1925; P. Z. Dąbrowski, Nauka o dziecku, Warszawa, 1926, s. 95-96.

69 A. Pankalla, A. Gołębiewska, op. cit., poz. 4.

70 Ibid., poz. 2. Aparat ten, opublikowany w 2009 r., zginął w 2014 r. z Instytutu Psychologii UAM. Tego typu przyrząd stosowany jest do dziś w badaniach kandydatów na kierowców i operatorów maszyn. 


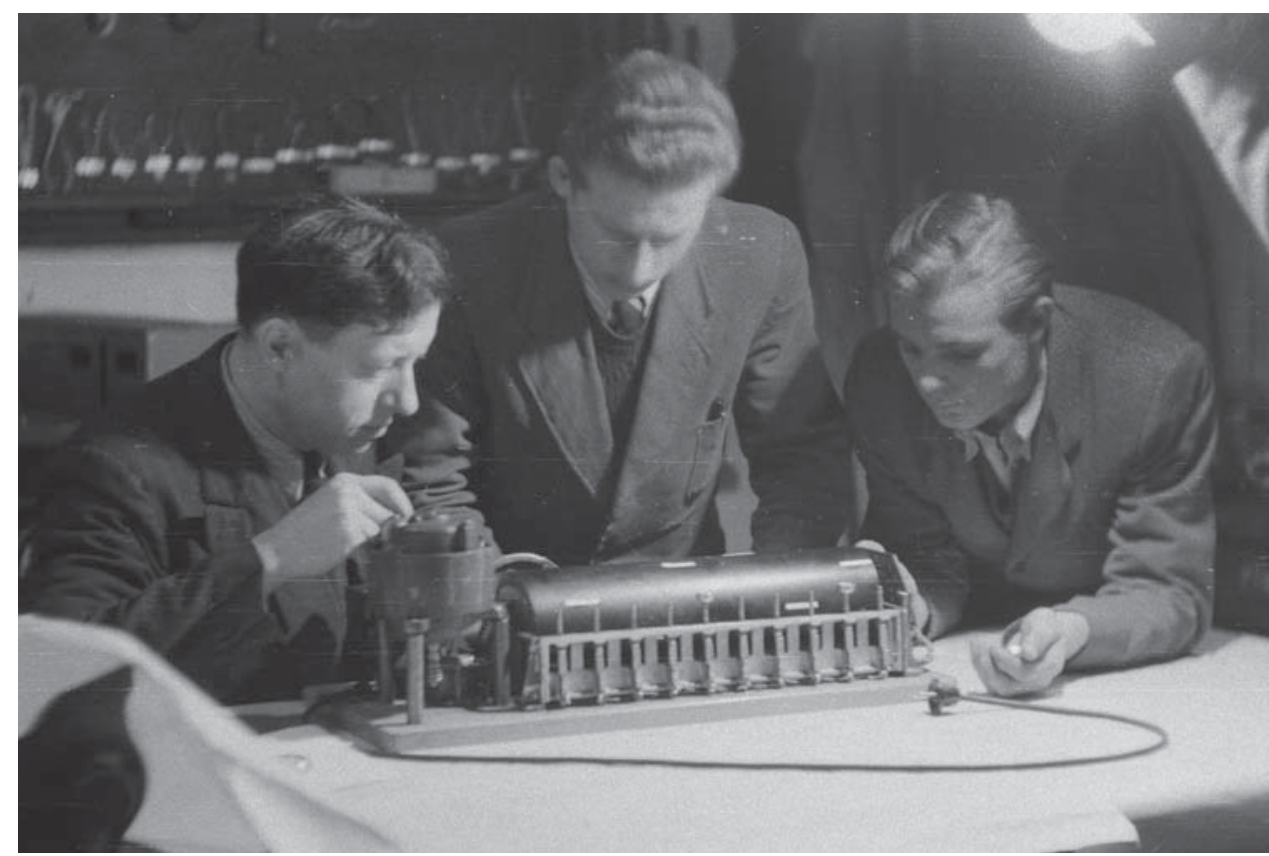

Ryc. 17a. Przy aparacie Piórkowskiego w pracowni mechanicznej Romana Juliana Calikowskiego, Fundacja Ośrodka KARTA, zesp. OK_0910_0001_0001.

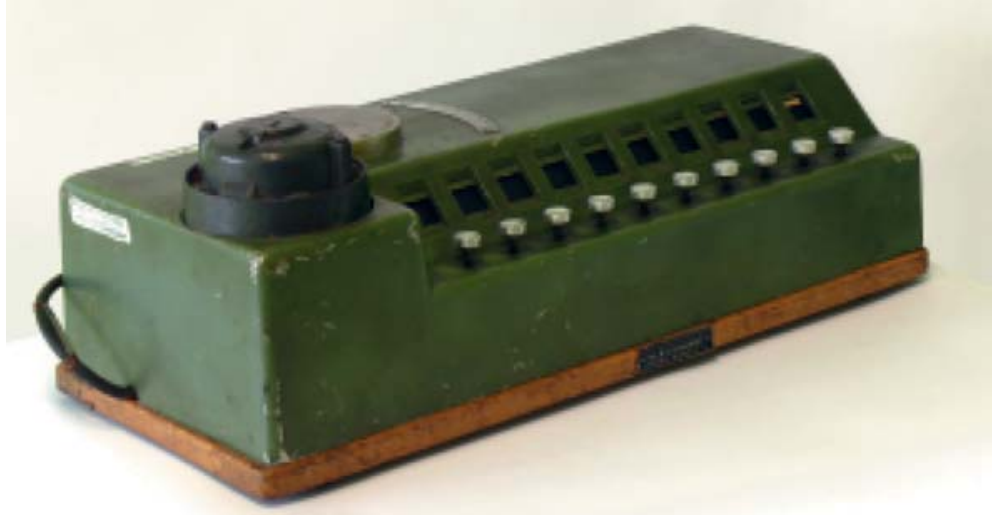

Ryc. 17b. Aparat Piórkowskiego, „Wytwórnia inż. R. Calikowskiego”, Kraków, przed 1950 r., wł. Instytut Psychologii, Uniwersytet Adama Mickiewicza w Poznaniu, fot. Roman Julian Calikowski (?).

Wiadomo, że firma inż. Romana Juliana Calikowskiego wykonywała lub montowała również proste przyrządy geodezyjne. Jej oferta obejmowała kompasy geologiczne jednoosiowe, busole topograficzne, klinometry. Co najmniej kilka z nich zachowało się w zbiorach Muzeum Uniwersytetu Jagiellońskiego ${ }^{71}$.

71 Karty katalogu naukowego przyrządów Romana Juliana Calikowskiego opracowane przez dr Małgorzatę Taborską, kustosz Muzeum UJ, 2008. 


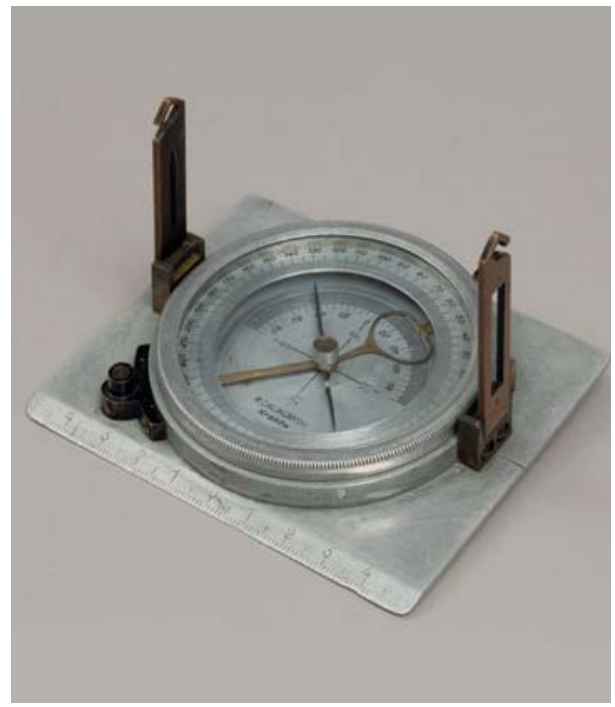

Ryc. 18. Busola magnetyczna z klinometrem, wyk. Roman Julian Calikowski, wł. Muzeum UJ, nr in. MUJ 17047 2163/V, ok. 1940 r., fot. Grzegorz Zygier.

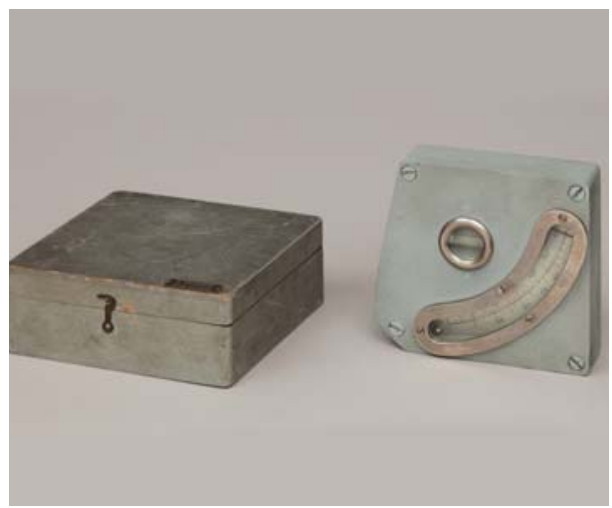

Ryc. 20. Klinometr z dioptriami 00-900, Muzeum UJ, nr inw. mt_n63, przed 1950 r., sygn. „R. CALIKOWSKI / Mechanik Precyzyjny/ KRAKÓW, GRODZKA 62", fot. Grzegorz Zygier.

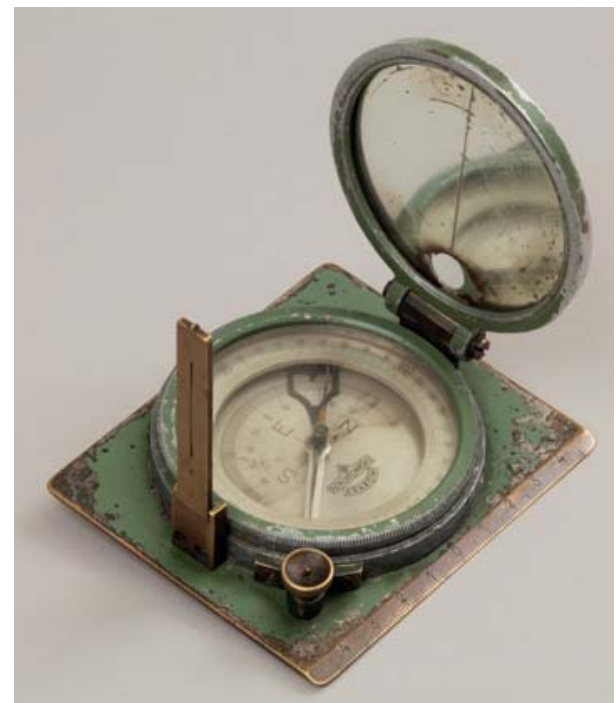

Ryc. 19. Busola topograficzna, przed 1950 r., sygn. „R. Calikowski/Kraków”, wł. Muzeum UJ, nr in. MUJ 17330, 2305/V, fot. Grzegorz Zygier.

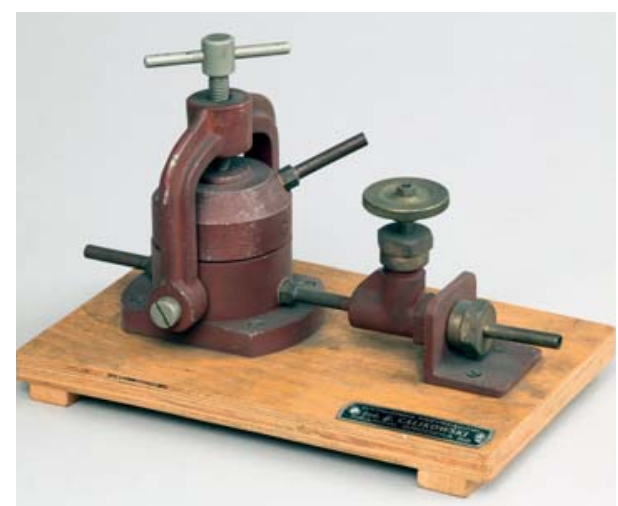

Ryc. 21. Miniautoklaw, sygn. „Wytwórnia Przyrządów Inż. R. Calikowski/ Kraków, Grodzka 62", przed 1950 r., wł. Muzeum UJ, nr in. mt_n62, 2826/V, fot. Grzegorz Zygier.

Firma realizowała liczne zamówienia krajowe. Doc. dr Leszek Sawicki (1924-2017), jeden z organizatorów Oddziału Dolnośląskiego Państwowego Instytutu Geologicznego wspominał, że na kompasy geologiczne wykonywane m.in. przez Calikowskiego trzeba było czekać pół roku72. Roman Julian przyjmował do naprawy i regulacji przyrządy geodezyjne lub też wykonywał do nich statywy. Na zachowanym w zbiorach Muzeum UJ statywie do niwelatora firmy „G. Gerlach" znajduje się tabliczka znamionowa firmy Cali- 

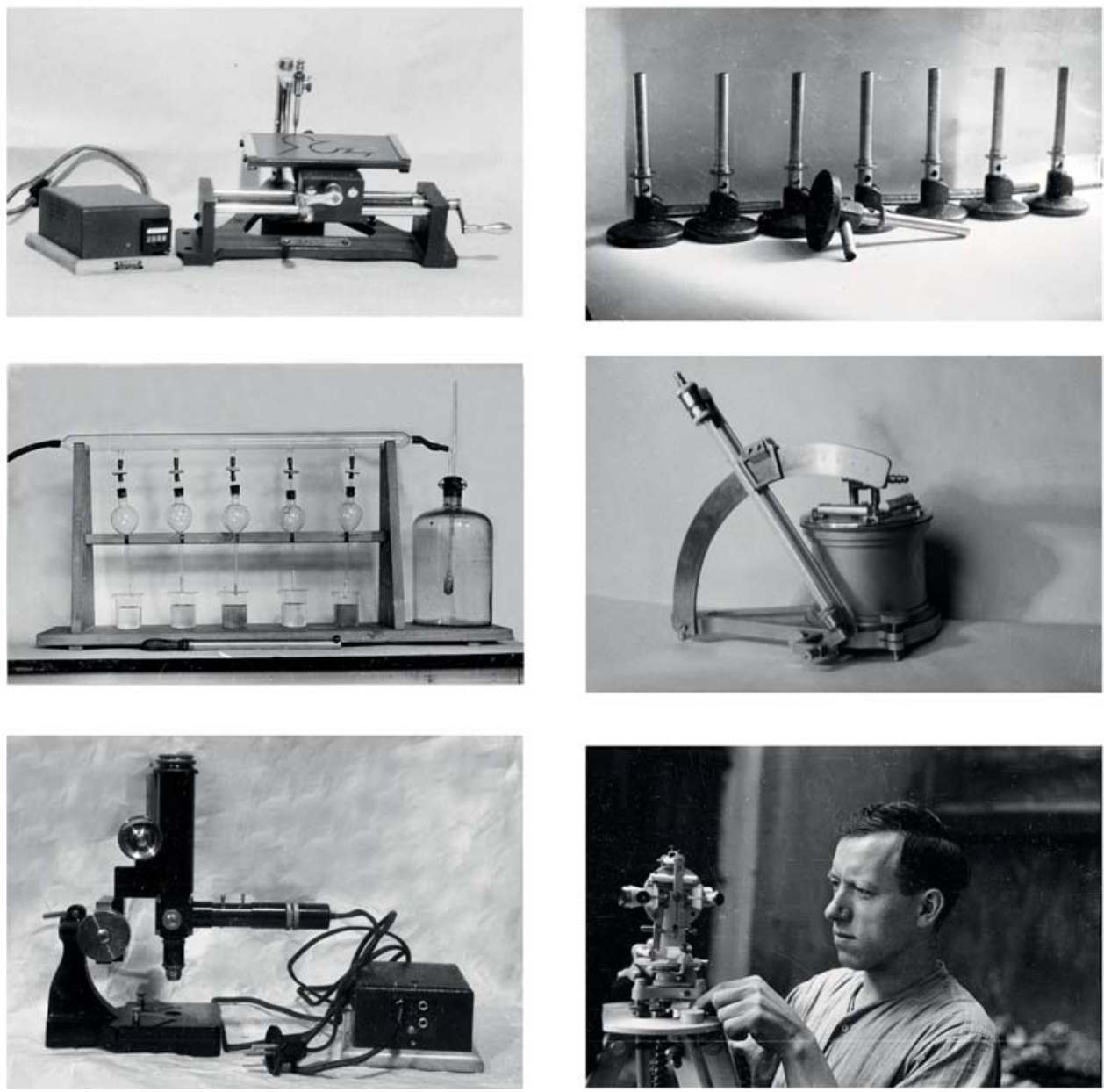

Fot. 22. Fotografie innych przyrządów wykonywanych w Wytwórni inż. Romana Calikowskiego, Fundacja Ośrodka KARTA, zesp. OK_0910_0001_0002.

kowskiego, podobnie jak na pudełku, w którym przechowywany jest ten przyrząd ${ }^{73}$. Archiwalne fotografie produktów firmowych ukazują również proste mikroskopy, aczkolwiek nie udało się jak dotychczas odnaleźć żadnego z nich ${ }^{74}$. Roman Julian Calikowski zajmował się również amatorsko fotografią, stąd zapewne jego firma przyjmowała do naprawy aparaty fotograficzne. W rodzinnych zasobach przechowywany był liczny zbiór fotografii ilustrujących wyposażenie warsztatu oraz produkty firmy ${ }^{75}$.

W 1951 r. Roman Julian z żoną Marią Cecylią z Otrębskich (1916-1986) i córką Marią Magdaleną przeprowadził się do Warszawy. W latach 1951-1952 kierował Katedrą Podstaw Konstrukcji Maszyn w Wojskowej Akademii Technicznej, a w latach późniejszych był

73 Teodolit sygnowany G. Gerlach Warszawa, nr in. MUJ 9483,537/N.

74 Fundacja Ośrodka KARTA [FOK], Kolekcja Romana Calikowskiego 1940-1956, zesp. PL_0001_OK_0910.

75 Zbiór ten został przekazany przez Panią Marię Magdalenę Calikowską do Fundacji Ośrodka KARTA. FOK, zesp. PL_0001_OK_0910. 
wykładowcą na Wydziale Mechaniki Precyzyjnej Politechniki Warszawskiej oraz na Wydziale Melioracji Wodnych Szkoły Głównej Gospodarstwa Wiejskiego ${ }^{76}$. Nadal związany był z Akademią Górniczo-Hutniczą. W kwietniu 1960 r. obronił pracę doktorską. Od roku 1948 należał do Stowarzyszenia Wychowanków Akademii Górniczo-Hutniczej w Krakowie $^{77}$. Zmarł 5 grudnia 1986 r., pochowany został na Cmentarzu Czerniakowskim w Warszawie.

\section{Podsumowanie}

Na kilka aspektów warto zwrócić uwagę podsumowując działalność Calikowskich jako mechaników związanych z krakowskimi szkołami wyższymi. Pierwszy aspekt to wyjątkowe tradycje rodzinne. W historii Uniwersytetu Jagiellońskiego był to jedyny przypadek ciągłości pracy spokrewnionych mechaników przez blisko 60 lat.

Analizując ich działalność, w szczególności braci - Romana i Ludwika, znajdujemy dobrą ilustrację współpracy mechanika i badacza. To tradycja sięgająca jeszcze wieków wcześniejszych, by przywołać choćby współpracę z mechanikami oświeceniowych badaczy - eksperymentatorów. Roman Calikowski współpracował z prof. Karolem Olszewskim wykonując na jego potrzeby badawczą aparaturę kriogeniczną. Także i Ludwik Calikowski włączony był w prace nad organizacją i unowocześnianiem wyposażenia krakowskiego laboratorium kriogenicznego. W naukach przyrodniczych i technicznych taka współpraca jeszcze w XIX w. należała do normalnych procedur pracy eksperymentalnej. Jednostkowo powstająca aparatura badawcza była pracą wspólną - wykonaną przez mechanika według wskazań i potrzeb badawczych uczonego.

Zachowane przyrządy i źródła archiwalne pozwalają na ocenę poziomu wyrobów z warsztatów Calikowskich. Szczególnie przyrządy do skraplania gazów wymagały perfekcyjnego wykonania i umiejętności ich obsługi. Pracowały one bowiem przy wysokich ciśnieniach, z udziałem gazów palnych, niejednokrotnie z narażeniem na eksplozję ${ }^{78}$. W ich konstrukcji stosowane i łączone były bardzo różnorodne materiały, poczynając od szkła poprzez drewno, elementy stalowe, mosiężne, gumę, tkaniny. Wykonanie takiego przyrządu wymagało umiejętności obróbki tych materiałów, zapewnienia szczelności i wytrzymałości aparatu oraz jego oprzyrządowania. Niezbędna była również wiedza z zakresu własności gazów w niskich temperaturach, która to wiedza w analizowanym okresie była cały czas w procesie intensywnego rozwoju. O wysokim poziomie wykonawstwa krakowskich przyrządów kriogenicznych świadczą liczne zamówienia na skraplarki Romana Calikowskiego składane przez zagraniczne laboratoria.

Pojawia się pytanie, na ile wykonywane w Krakowie skraplarki miały charakter nowatorski w swej koncepcji i konstrukcji. Nie były to całkowicie nowe urządzenia. Tak Roman Calikowski, jak i Władysław Grodzicki byli mechanikami wykonującymi aparaty według

FOK, Wstęp do Inwentarza Zespołu „Kolekcja Romana Calikowskiego”, www.foto.karta.org.pl/gfx/fotokarta/ userfiles/_public/ok_0910_calikowski_roman.pdf [dostęp 10.03.2018].

77 Legitymacja członkowska $\mathrm{nr} 168 \mathrm{z}$ däru Marii Calikowskiej przekazana do Archiwum UJ.

78 Znany jest jeden przypadek eksplozji gazów, kiedy to w 1894 r. w pracowni K. Olszewskiego rozsadzeniu uległ manometr gazowy podczas sprężania etylenu. Zniszczony manometr zachowany jest w zbiorach Muzeum UJ, nr MUJ 4449, 460/V. 
wskazówek i rozwiązań konstrukcyjnych autorstwa Karola Olszewskiego. Tenże też nie był w pełni autorem oferowanych przez mechaników skraplarek. Ich konstrukcja opierała się na znanym dużo wcześniej zjawisku adiabatycznego rozprężania gazu i zastosowaniu przeciwprądowego ochładzania gazu skraplanego. Aparaty tej konstrukcji opracowane zostały około 1895 r. niezależnie przez Carla Paula Gottfrieda Lindego (1842-1934) i Williama Hampsona (1854-1926). Zastąpiły one stosowane do tej pory tzw. aparaty kaskadowe. Karol Olszewski uznając przyrząd typu Hampsona jako bardziej odpowiedni do prac laboratoryjnych wprowadzał własne modyfikacje, zapewniające m.in. mniejsze zużycie gazów i energii, bezpieczeństwo i komfort pracy z aparatem. Olszewski był sprawnym konstruktorem i praktykiem. Sam wykonywał niektóre przyrządy ${ }^{79}$. Z dużym prawdopodobieństwem można twierdzić, że mechanicy wykonywali przyrządy realizując proponowane przez niego rozwiązania.

To co charakterystyczne dla wytwórni Romana Juliana to duża różnorodność asortymentu. Nie były to raczej urządzenia specjalnie skomplikowane. Większość z nich, jak choćby opisywany tachistoskop Nieczajewa czy kompasy geodezyjne, były konstrukcjami wówczas już znanymi. Nie były one autorskimi rozwiązaniami Romana Juliana. Oprócz opisanych w artykule narzędzi geodezyjnych i psychotechnicznych, mikroskopów i in. mechanik podjął się wykonania kilku specjalistycznych urządzeń dla Technikum Budowlanego w Lublinie. One również były konstrukcjami znanymi ${ }^{80}$. Planowane jako pomoce dydaktyczne, nie zostały już zrealizowane ze względu na likwidację firmy i przymusowy wykup maszyn.

W kolejnych pokoleniach rodziny Calikowskich znajdujemy jej przedstawicieli związanych nadal z wyższymi uczelniami, ale już nie jako mechaników, lecz pracowników naukowych ${ }^{81}$.

\section{Podziękowania}

Składam serdeczne podziękowania Paniom Marii Magdalenie Calikowskiej, wnuczce Romana i córce Romana Juliana oraz Annie Calikowskiej, wnuczce Ludwika Calikowskiego a zarazem córce jego syna Jana za życzliwe przyjęcie, za liczne informacje rodzinne i udostępnienie materiałów z zasobów rodzinnych. Serdecznie dziękuję Pani doc. dr hab. Elżbiecie Szczepaniec-Cięciak za konsultacje i fotografie, które wykorzystałam w artykule.

Wiadomości i materiały udostępnione życzliwie przez dr hab. Andrzeja Wójcika prof. PAN umożliwiły mi prawidłową atrybucję przyrządów geologicznych zachowanych w zbiorach UJ, ilustrujących różnorodność produkcji Romana Juliana Calikowskiego.

79 Z. Wojtaszek, H. Kuzyk, A. Morzyniec, J. Dubowy, K. Łopata, Karol Olszewski, Warszawa-Kraków 1990 (Zeszyty Naukowe UJ, t. 899)

80 Były to: 1 aparat Vicata, 2 aparaty Cassagrande ’a i 6 edometrów wraz z obciążnikami. Aparat wg Louisa Vicata służył do badania czasu wiązania spoiw, aparat Cassagrande`a służył do badania spoistości gruntu, edometr to przyrząd do laboratoryjnego badania ściśliwości gruntu pod obciążeniem.

81 Jan Calikowski (1924-1997) syn Ludwika praktykował w warsztacie Romana Juliana, gdzie nabył umiejętności pracy warsztatowej. Ukończył studia na Wydziale Geologicznym UJ w 1953 r. W latach 1948-1949 r. pracował w Głównym Instytucie Naftowym w Krakowie, a następnie związał się z Instytutem Geologicznym w Warszawie. Stworzył nowy kierunek - geochemię naftową. Wraz z Barbarą Gondek zorganizował w warszawskim instytucie nowoczesne laboratorium geochemiczne, którym kierował do 1982 r. („Wiadomości PIG 1999-02", nr 93). 
Dziękuję Fundacji Ośrodka Karta w Warszawie oraz Archiwum UJ za udostępnienie fotografii, jak również Panu prof. Andrzejowi Pankalli i Pani Monice Mielcarek z Uniwersytetu Adama Mickiewicza w Poznaniu za fotografie i informacje na temat przyrządów psychotechnicznych.

Recenzentom niniejszego artykułu dziękuję za poświęcony czas i cenne uwagi do tekstu.

\section{Bibliografia}

\section{Materiały archiwalne}

Arch. UJ (Archiwum UJ), sygn. SII 620, teczki osobowe: Roman Calikowski, Ludwik Calikowski, Leon Kowalski, Karol Jetleb.

Arch. UJ. SII 815 Fizjologia 1849-1937.

Arch.M.Kr. (Archiwum Miasta Krakowa) Miejski Zarząd Przemysłu w Krakowie sygn. 29/1186/351.

Rodzinne zbiory Anny Calikowskiej i Marii Magdaleny Calikowskiej przekazane do Archiwum UJ w 2018 r.

Kolekcja Romana Calikowskiego 1940-1956, Fundacja Ośrodka KARTA, Warszawa, zesp. PL_0001_OK_0910.

Materiały archiwalne w zasobach Muzeum UJ, niezinwentaryzowane.

\section{Literatura przedmiotu}

Burczyk-Marona D., Kuzyk H., K. Olszewski, Z. Wróblewski. 100-lecie skroplenia tlenu. Katalog wystawy, Kraków 1983.

Dąbrowski P. Z., Nauka o dziecku, Lwów-Warszawa, 1926.

Gablankowski M., Mechanicy Uniwersytetu Jagiellońskiego (1787-1939), Praca magisterska, Kraków 2004.

Gablankowski M., Mechanicy Uniwersytetu Jagiellońskiego [w:] Polscy wytwórcy aparatury naukowej, red. A. Strzałkowski, Kraków 2006 (Monografie Polskiej Akademii Umiejętności, t.10), s. 45-60.

Franaszek P., Collegium Witkowskiego, „Alma Mater. Miesięcznik Uniwersytetu Jagiellońskiego" nr 155, 2013 s. 15-25.

Franaszek P., Collegium Witkowskiego, Kraków 2014.

Jaroszyński T., Metody badań psychologicznych w szkole, Warszawa 1925.

Olszewski K., Przyrządy do skroplenia powietrza i wodoru, „Rozprawy Wydziału Matematyczno-Przyrodniczego Akademii Umiejętności", Seria A, tom 2. Dział A, 1902, s. 457- 470 .

Pankalla A., Gołębiewska A., Urządzenia psychotechniczne Instytutu Psychologii w Poznaniu z lat 1915-2005. Katalog wystawy pt. Gabinet psychotechniczny, Poznań 2009.

Relacje pracowników Uniwersytetu Jagiellońskiego o ich losach osobistych i dziejach uczelni w czasie drugiej wojny światowej, oprac. J. Michalewicz, Kraków 2005.

Uniwersytet Jagielloński, Złota Księga Wydziału Chemii, t. 1, red. E. Szczepaniec-Cięciak, Kraków 2000.

Wojtaszek Z., Kuzyk H., Morzyniec A., Dubowy J., Łopata K., Karol Olszewski, Warszawa-Kraków 1990 (Zeszyty Naukowe UJ, t. 899). 
dr hab. Ewa Wyka, prof. PAN - historyk nauki, profesor nadzwyczajny w Instytucie Historii Nauki im. L. i A. Birkenmajerów PAN, kustosz Muzeum Uniwersytetu Jagiellońskiego. Obszar zainteresowań badawczych: historia nauk matematycznoprzyrodniczych, historia i ewolucja instrumentarium naukowego; arystokratyczne i akademickie kolekcje przyrządów naukowych XV-XX w.; wytwórczość przyrządów naukowych; muzealnictwo nauki i techniki; popularyzacja nauki. E-mail: ewawyka@gmail.com

Data zgłoszenia artykułu: 23 maja 2018

Data przyjęcia do druku: 14 stycznia 2019 